\title{
Light nonmethane hydrocarbons in seawater
}

\author{
C. Plass-Dülmer, R. Koppmann, M. Ratte, and J. Rudolph \\ Institut für Atmosphärische Chemie. Forschungšentrum Jülich, Jülich, Germany
}

\begin{abstract}
A database of dissolved $\mathrm{C}_{2}-\mathrm{C}_{4}$ hydrocarbons in the surface water of the oceans is compiled based on more than 1000 measurements. Hydrocarbon emission rates are calculated using a diffusive microlayer approach and climatologic wind data. This database is used to calculate averages and ranges of variation, and an attempt is made to identify the environmental factors which have an impact on the hydrocarbons dissolved in seawater. The paper focuses on data obtained in situ since other techniques generally contain larger uncertainties. Mean concentrations are $134 \mathrm{pmol} / \mathrm{L}$ for ethene, $59 \mathrm{pmol} / \mathrm{L}$ for propene, and $37 \mathrm{pmol} / \mathrm{L}$ for 1 -butene. Alkane concentrations are lower with an average value of $22 \mathrm{pmol} / \mathrm{L}$ for ethane and less than $14 \mathrm{pmol} / \mathrm{L}$ for the other alkanes and acetylene. Ninety percent of the concentrations of an individual compound generally ranges within an order of magnitude. Ethene concentrations are significantly anticorrelated with the transfer velocities of the sea-air exchange $(r=-0.49$; $r_{0.01}=0.29$ ). Ethene concentrations are not correlated with the solar radiation, chlorophyll $a$, and the water temperature. Averaged emissions of $\mathrm{C}_{2}-\mathrm{C}_{4}$ hydrocarbons extrapolated to the global ocean of $2.1 \times 10^{12} \mathrm{~g} / \mathrm{yr}$ are calculated, with ethene alone contributing about $40 \%$ to the total. Thus the oceanic source is on the low side of previous estimates and plays a minor role in global budgets compared to continental sources.
\end{abstract}

\section{Introduction}

Ocean emissions of light nonmethane hydrocarbons (NMHC) are important for both their impact on marine atmospheric chemistry and their contribution to global NMHC budgets. Owing to the large area of the ceans, even small fluxes of NMHC per unit area could result in large global oceanic emissions. Rudolph and Ehhall [1981] concluded that the oceans are supersaturated with light NMHC and estimated that NMHC can have similar turnover rates as methane in the marine atmosphere. However, their estimates were based only on measurements in the atmosphere and the NMHC concentrations in seawater published by Swinnerton and Lamontagne [1974]. Thus they were not able to compare atmospheric observations with actual occanic emissions. The first simultaneous measurements of NMHC in the atmosphere and in the ocean were published by Bonsang et al. [1988]. They measured NMHC concentrations in the surface water of the Indian Ocean which were considerably higher than the concentrations: observed by Swinnerton and Lemontagne [1974]. Also, they observed unusually high atmospheric NMHC levels, but they did not give a budget comparing atmospheric removal with oceanic sources. The oceanic emission estimated by Bonsong et al. [1988] indicated that on a global scale the oceans might be a substiantial source for atmospheric NMHC. Different results were found by other groups who makle comparable studics in other ocean areas [Plass et al., 1992: Plass-Diilmer et al., 1993; Donalue and l'rinn, 1993]. The most common approach for

Copyrighe 1995 by the Americin (ieophysicul Union.

P'aper number 94GB02416.

0886-6236/95/94GB-02416\$10.00 calculating oceanic emissions utilizes the measured seawater concentrations of NMHC and transfer rates derived from oceanatmosphere exchange models. Such estimates are lower than oceanic emissions by Bonsang ef al. [1988]; however, they can differ by an order of magnitude [Plass-Diilmer et al.. 1993] mainly due to differences between the chosen data sets of dissolved hydrocarbons.

Light hydrocarbons dissolved in seawater have been measured during the past 25 years in more than 1000 samples. In the early measurements the major interest focused on oil exploration and oil pollution. Brooks and Sackett [1973]. Brooks et al. [1973], and Frank et al. [1970] showed drastic increases of saturated hydrocarbons in the proximity of natural oil seeps and anthropogenic sources of oil pollution. In order to assess the extent of the oil pollution in the marine environment, Swinnerton and Lamontagne [1974] proposed baseline concentrations of $\mathrm{C}_{1}-\mathrm{C}_{4}$ hydrocarbons estimated from all available open ocean data. These were used to set up a criterion in order to differentiate between open ocean clean water and water contaminated by hydrocarbons. Yet, the parameters which determine the concentrations of dissolved NMHC in the world's oceans are still not identified. Swinnerton and Lamontagne [1974] summed up the current understanding in soine general observations: (1) The concentrations secm to be consistent from area to area. (2) The concentrations peak in the upper $0.150 \mathrm{~m}$. (3) In this layer the olefines are generally more abundant than their saturated homologs. They attributed the peak concentrations to processes occurring faster than physical mixing, most probably corrclated with the primary productivity. However, in anoxic waters they observed different vertical structures and concluded that the production processes in anoxic and oxygenated waters are different. 


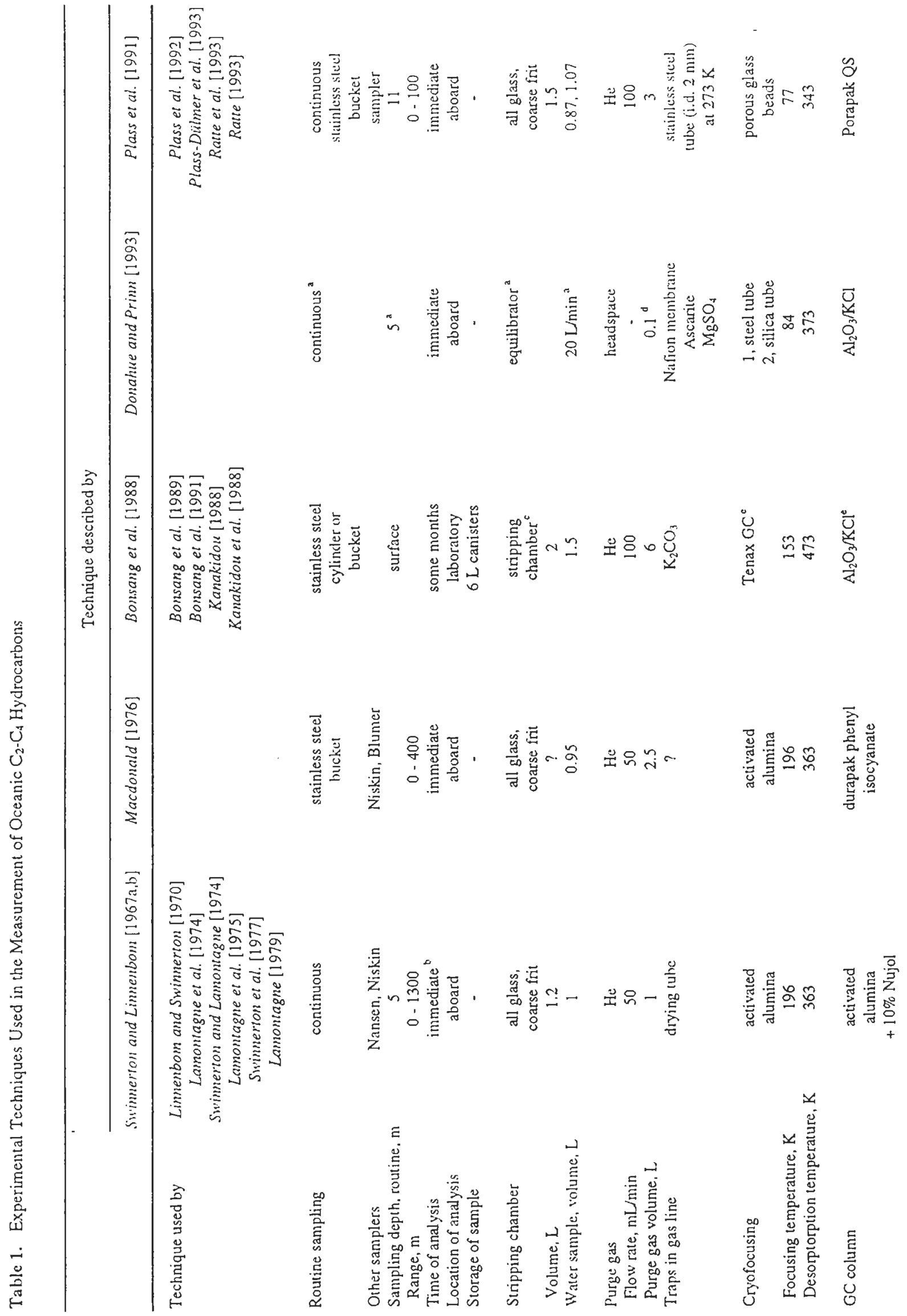


From the point of vicw of atmospheric chemistry, the knowledge of NMHC concentrations in ocean water is of limited value as long as no simultancous measurements of the seab-air exchange rates are reported. However, emission estimates can be based on exchange rates derived from climatological data and the concentrations of NMHC. This paper presents our recent results and makes use of the large number of measurements now available to provide an overview of NMHC concentrations in the world's oceans. This database is then used to discuss possible causes for variations, and an attempt is made to identify factors which have an impact on the NMHC concentrations in seawater. Finally, the database will be used for a global estimate of oceanic NMHC emissions.

\section{Experimental Methods}

All measurements of NMHC in scawater are more or less based on the method developed by Swinnerton and Linnenbom [1967a]. They achieved detection limits of $10^{-12} \mathrm{~mol} / \mathrm{L}$ of seawater using a purge and trap technique combined with gas chromatography using a flame ionization detector (GC-FID). A short overview of the sampling methods, the handling and storage of the samples, and the analytical techniques used by the different authors is given in Table 1 .

Generally, stripping chambers similar to the one described by Swinnerton and Linnenbom [1967a] have been used. They consist of a glass cylinder with a coarse glass frit at the lower end. The water sample is transfered into the cylinder, and the dissolved gases are purged out of the water with helium. Donchue and Prinn [1993] used an equilibrator (see Table 1) and took samples from the headspace. They had no opportunity to test the equilibrator before the cruise and therefore estimate the accuracy of the overall method conservatively at $30-50 \%$. Bonsang and coworkers first used a stripping chamber [Bonsung et al., 1988]; later they reported that the water samples were outgassed with helium by a headspace equilibration technique [Bonsang et al., 1991]. However, no details are given in the latter case.

The purge gas with the extracted hydrocarbons is dried by different types of traps mounted in the gas line (Table 1). Then the dried gas samples are cryogenically focused on columns (Table 1). Donahue and Prinn [1993] additionally applied a $\mathrm{CO}_{2}$ and ozone trap since they used the same experimental setup as for the measurement of ambient air. No contamination due to the traps was reported, except for small amounts of 2-methylpropene observed by Donahue and Prinn [1993] in blank runs.

Details of the chromatographic columns are given in Table 1. Gencrally, the relevant $\mathrm{C}_{2}$ - $\mathrm{C}_{4}$ hydrocarbons were sufficiently separated. In the early measurements by Swinnerton and Linnenboin [1967a,b], Brooks and Sackell [1973], and Brooks et al. [1973], ethene and ethane were not seperated. Macdonald [1976] did not report cthane concentrations for his measurements in 1974 due to adsorption problems during the cryogenic focusing. The reported accuracies of the measured NMHC concentrations in scawater are between 10 and $50 \%$ (references stated in Table 1).

A completely difterent technique (not mentioned in Table 1) was developed by Brooks and Sackell [1973] and Brooks et al. [1973]. Using this methoxl, they were able to measure relative 
concentrations in contaminated areas over short time intervals. They used a booster pump with restricted inflow which strips about $50 \%$ of the dissolved gases from the water [Brooks and Sackett, 1973]. The stripped gases were directly injected onto the column without a focusing step. Additionally, in open ocean areas they report having used the technique of Swinnerton and Linnenbom [1967a], but for their results they do not clearly identify the technique used.

In all the investigations discussed here the sampling of the water was done either by continuous water intake lines or with water samplers. Some investigators compared different sampling methods in order to rule out contamination caused by either of the methods. Lamontagne et al. [1974] used Niskin samplers and a ship intake line. Macdonald [1976] sampled with stainless steel buckets and used Niskin and Blumer samplers. PlassDülmer et al. [1993] used a stainless steel bucket for surface samples and an intake line in $11 \mathrm{~m}$ depth. None of these authors reported significant differences in the measured hydrocarbon concentrations which could be ascribed to sampling artifacts.

Most of the measurements were done immediately after sampling, hereafter refered to as in situ methods. In their first investigations, Swinnerton and Linnenborn [1967a,b] stored the water samples in 1-L glass bottles closed with tapered ground-glass stoppers; details about the conditions of storage were not given. These samples were reported to be stable for intervals between 2 hours and 1 month. However, they also observed differences between in situ samples and samples taken to the laboratory (R.A. Lamontagne, personal communication, 1992). Macdonald [1976] reported an increase in hydrocarbon concentrations in glass bottles when kept in the laboratory for some hours; again, the conditions were not described. Ratle et al. [1993] found increasing concentrations in quartz bottles exposed to sunlight, whereas samples kept in the dark showed no significant change during the observation period of 8 days (sample bottles were kept in an open container on deck of the research ship at ambient seawater temperature (between 280 and $290 \mathrm{~K}$ )[Ratte et al., 1993]). Plass-Dïlmer [1992] observed constant $\mathrm{C}_{2}-\mathrm{C}_{4}$ hydrocarbon concentrations in water samples stored in stainless steel cylinders (electropolished) at about $300 \mathrm{~K}$ for 4 days; only ethane concentrations were significantly enhanced in two of the eight samples. Thus lydrocarbon concentrations in seawater samples have been reported to bc stable in glass bottles in the dark or in stainless steel cylinders for several days up to a few weeks.

Swinnerton and Linnenbom [1967b], Swinnerton et al. [1977], and Frank et al. [1970] reported the addition of chemicals to the water sample in order to retard bacterial action. While no effect on NMHC concentrations is reported for the addition of sodium azide to the samples, the addition of mercuric chloride changed ethene to ethane and propene to propane [Swinnerton and Limnenbom, 1967b]. Plass et al. [1991] used filters (glass fiber, pore size $0.8 \mathrm{~mm}$ and $1.2 \mathrm{~mm}$ ) to prevent phytoplankton and particles from entering the stripping chamber. They observed no intluence of the filtering procedure on the NMHC concentrations.

Bonsang et al. [1988, 1989, 1991] stripped the hydrocarbons from the water sample aboard the ship, but they stored the purge gas with the extracted hydrocarbons in 6-L stainless steel cylinders. The gas samples were analyzed subsequent to the cruise. Bonsung et al. [1988] reported having checked the cylinders for storage stability. In atmospheric samples the alkane concentrations remained fairly constani, but the light alkene concentrations tended to increase. For most alkenes the increases were between 30 and $60 \%$ with a maximum of 250 parts per trillion (ppt) during periods of 9 and 40 days [Kanakidou, 1988].

\section{Database}

The global distribution of measurement sites for dissolved NMHC in surface seawater is shown in Figure 1. Only measurements from the upper $15 \mathrm{~m}$ are considered because in this case, vertical homogeneity can generally be assumed [PlassDülmer et al., 1993]. This upper layer controls the impact of the oceans on atmospheric chemistry since the emissions into the atmosphere are determined by the concentrations in this layer. About 1150 measurements have been published in this depth range.

For better clarity we arranged the available data into 44 data sets (Table 2). A data set consists of a minimum number of two measurements which were conducted in a single series by one investigator. Each data set is limited in time to a maximum of about 1 month and in space according to ocean regions or with a maximum extension of about $30^{\circ}$ of latitude and longitude. Additionally, to data sets taken from the literature, we present recent data obtained in the Mediterranean Sea, North Sea, and Atlantic Ocean by Ratte [1993](data sets 39-42 in Table 2).

The data sets are categorized according to different sample treatments (compare Table 2). We distinguish between data sets obtained by in situ measurements (in situ), chemicals added to the water sample (chemicals added), stripped hydrocarbons with purge gas stored in cylinders (cylinder), and data sets with no clear specification of the sample treatment (not specified). More than $70 \%$ of the data were obtained by in situ methods (compare Table 2). There are a few sample sets which cannot be unambiguously assigned to a category, as for the early measurements reported by Swinnerion and Lamontagne [1974] (data sets 1-17). It is only mentioned that most of the measurements were made aboard ship. For some of the data sets. additional information is available from further references. According to Lamontagne et al. [1974] data sets 12-16 were measured in situ. For data set 11. Swinnerton et al. [1977] mentioned the addition of sodium azide. Mercuric chloride has been added to samples collected by Brooks et al. [1973] which were analyzed by J.W. Swinnerton. These samples are probably those of data sets 9 and 10 for two reasons: First, Swinnerton and Lomontagne [1974] mention that these samples were taken in collaboration with J.E. Brooks, and second, the sampling times and locations agree.

In order to have a consistent database, results from GC-FL: systems which were not capable of seperating alkenes and alkanes were rejected (data set 43 by Brooks and Sackett [1973]: clata set 44 by Frank et al. [1970]; and the measurement numbers 11, 15, 16, 17, and 22 stated by Swinnerton and Lamontagne [1974]). Additionally, data obtained in rivers. lakes, near docksides, and on the ice shelf (results 18, 79, 133143 stated by Swinnerton and Lamontagne [1974]) as well as a single measurement inside a lagoon [Bonsang et al., 1989] ar. not included. 


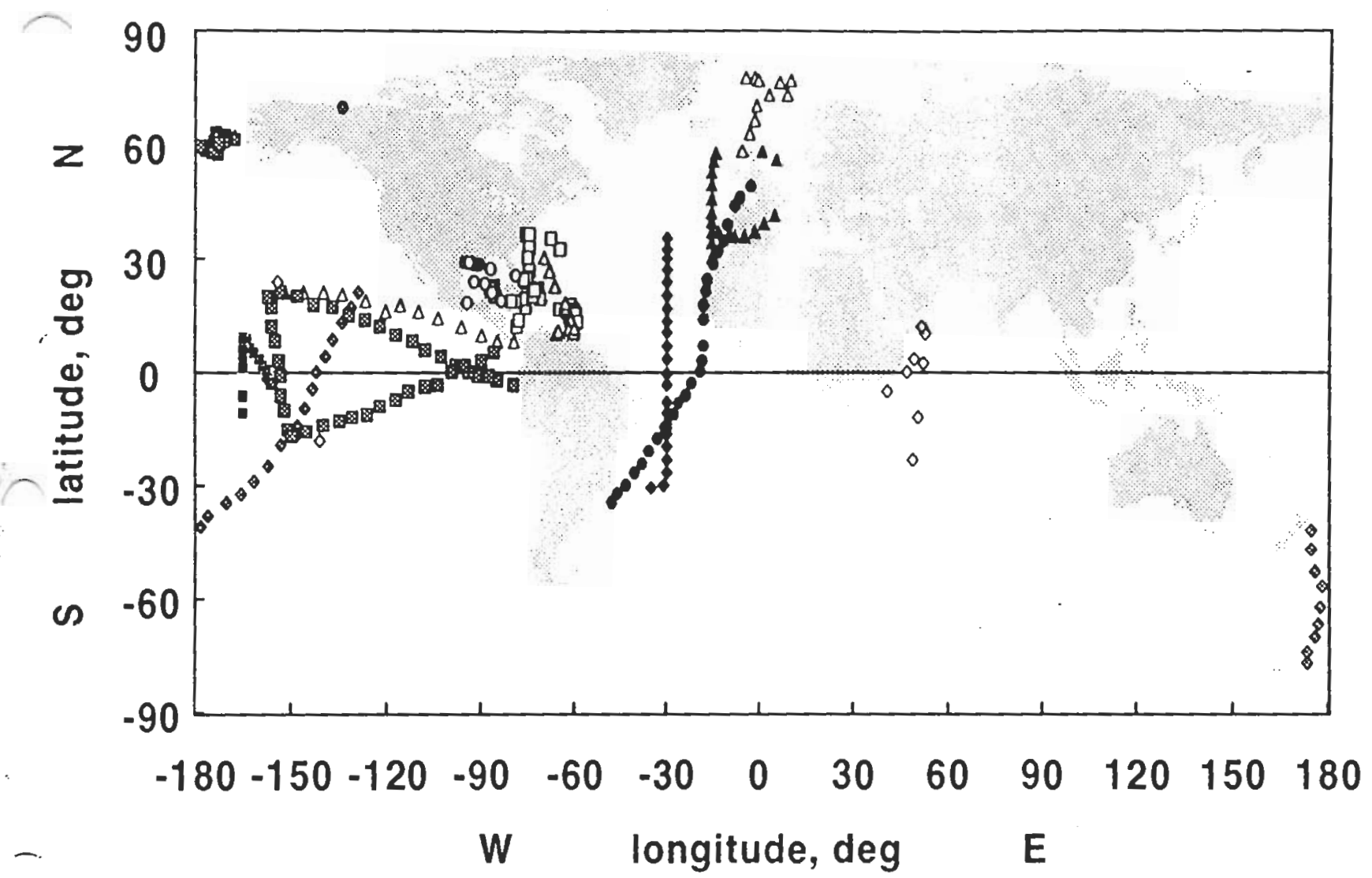

Figure 1. The global distribution of measurement sites of dissolved nonmethane hydrocarbons (NMHC). The symbols used, data sets, year of investigation, and reference(s) are as follows: in situ data; shaded diamonds, 12-16, 1972, and Swinnerton and Lamontagne [1974]; shaded squares, 18-24, 1974, 1977, and Lamontagne ef al. [1975] and Lomontagne [1979]; shaded circles, 25-26, 1974-75, and Macdonald [1976]; solid diamonds, 3133, 1988, and Plass et al. [1992]; solid circles, 34-37, 1989, and Plass-Dülmer et al. [1993]; solid squares, 38, 1990, and Donahue and Prinn [1993] and N.M. Donahue (personal communication, 1991); solid triangles, 3942, 1991, and Ratte [1993]. Other data: open squares, 14, 17, 1968-73, and Swinnerton and Larnontagne [1974]; open triangles, 5-8, 1971, and Swinnerton and Lamontagne [1974]; open circles, 9-11, 1971-72, and Swinnerton and Lamontagne [1974] and Swinnerton et al. [1977]; open diamonds, 27-30, 1985, 1987, and Bonsang et al. [1988, 1989].

\section{Concentrations of $\mathrm{C}_{2}-\mathrm{C}_{4}$ Hydrocarbons in Surface Seawater2}

In this section the data are presented with respect to the sample treatment as introduced in section 3. Scasonal and regional differences will be discussed in section 5 .

\subsection{Overview of Measured Concentrations}

Table 3 summarizes the averages and the ranges of neasured concentrations in the various data sets. In Table 4 the averages and ranges of in situ measurements are compared with non-in situ measurements. The in situ results are generally comparable to those of the not specified category, whereas concentrations from measurements of the other categories are larger by factors ff 3-20. However, the number of measurements is substantially lower than in the in situ and not specified categories. The order of abundance for the various hydrocarbons is similar in all categories. For the in situ results, ethene concentrations are on average the largest (134 pmol/L) followed by propene ( $59 \mathrm{pmol} / \mathrm{L}$ ) and the sum of butenes ( $37 \mathrm{pmol} / \mathrm{L}$ ). The alkane concentrations are of lower levels than the alkene concentrations with ethane ( $22 \mathrm{pmol} / \mathrm{L}$ ) as the most abundant compound. Acetylene concentrations ( $14 \mathrm{pmol} / \mathrm{L}$ ) make up about $5 \%$ of all $\mathrm{C}_{2}-\mathrm{C}_{2}$ hydrocarbons.

The latitudinal distributions of ethene and propene concentrations are shown in Figure 2. Ethene concentrations range over almost 3 orders of magnitude, $90 \%$ of the in situ clata is belween $42 \mathrm{pmol} / \mathrm{L}$ and $358 \mathrm{pmol} / \mathrm{L}$ (Table 3). No clear trend of concentrations with latitude exists. Propene concentrations depict a similar picture on a lower level. Figure 3 shows ethane and propane concentrations as function of latitude. The ranges of all obscrved concentrations again are about 3 orders of magnitude and $90 \%$ of the in situ data is found within the range of 1 order of magnitude (Table 4).

Figure 4 shows histograms of the ethene and cthanc data on a logarithmic concentration scale. The in situ concentrations of 
Table 2. Data Sets of Measured Hydrocarbon Concentrations in Surface Water

\begin{tabular}{|c|c|c|c|c|c|c|c|}
\hline $\begin{array}{l}\text { Data } \\
\text { Set }\end{array}$ & $\begin{array}{l}\text { Numbe } \\
\text { Sampl }\end{array}$ & rof & Latitude & Longitude & Area ${ }^{x}$ & Callegory" & Refierence \\
\hline 1 & 7 & June, 1968 & $22^{\circ}-38^{\circ} \mathrm{N}$ & $71^{\circ}-77^{\circ} \mathrm{W}$ & $C, n-A$ & $?$ & Swinnerton and Lamontagne [1974] \\
\hline 2 & 18 & April, 1969 & $10^{\circ}-18^{\circ} \mathrm{N}$ & $59^{\circ} .65^{\circ} \mathrm{W}$ & $\mathrm{C}, \mathrm{n}-\mathrm{A}$ & $?$ & Swimnerton and Lamontagne [1974] \\
\hline 3 & 3 & Dec., 1969 & $32^{\circ}-37^{\circ} \mathrm{N}$ & $64^{\circ}-75^{\circ} \mathrm{W}$ & $C, n-A$ & $?$ & Swinnerlon and Lamontagne [1974] \\
\hline 4 & 5 & May, 1970 & $12^{\circ}-18^{\circ} \mathrm{N}$ & $75^{\circ}-79^{\circ} \mathrm{W}$ & $\mathrm{C}$ & $?$ & Swinnerlon and Lamontagne [1974] \\
\hline 5 & 53 & May, 1971 & $10^{\circ}-30^{\circ} \mathrm{N}$ & $60^{\circ}-70^{\circ} \mathrm{W}$ & $\mathrm{C}, \mathrm{n}-\mathrm{A}$ & $?$ & Sivimerlon and Lamontagne [1974] \\
\hline 6 & 30 & May to June, 1971 & $8^{\circ}-16^{\circ} \mathrm{N}$ & $80^{\circ}-110^{\circ} \mathrm{W}$ & e-P & $?$ & Swimerton and Lamontagne [1974] \\
\hline 7 & 36 & June, 1971 & $16^{\circ}-21^{\circ} \mathrm{N}$ & $116^{\circ}-152^{\circ} \mathrm{W}$ & $\mathrm{n}-\mathrm{P}$ & $?$ & Siwimerton and Lamontagne [1974] \\
\hline 8 & 95 & Aug., 1971 & $58^{\circ}-78^{\circ} \mathrm{N}$ & $6^{\circ} \mathrm{W}-10^{\circ} \mathrm{E}$ & $n-A$ & $?$ & Swinnerion and Lamomagne $[1974]^{c, d}$ \\
\hline 9 & 7 & June, 1971 & $28^{\circ}-29^{\circ} \mathrm{N}$ & $92^{\circ}-95^{\circ} \mathrm{W}$ & G & a & Swinnerton and Lamontagne [1974] \\
\hline 10 & 13 & Oct., 1971 & $19^{\circ}-29^{\circ} \mathrm{N}$ & $84^{\circ}-94^{\circ} \mathrm{W}$ & $\mathrm{G}$ & a & Swinnerton and Lamontagne [1974] ${ }^{c}$ \\
\hline 11 & 9 & June, 1972 & $25^{\circ} \mathrm{N}$ & $79^{\circ} \mathrm{W}$ & off Miami & a & Swinnerton and Lamontagne [1974] \\
\hline 12 & 10 & Nov., 1972 & $13^{\circ}-21^{\circ} \mathrm{N}$ & $129^{\circ}-134^{\circ} \mathrm{W}$ & $n-P$ & $\mathrm{i}$ & Swinnerton and Lamontagne $[1974]^{\circ}$ \\
\hline 13 & 26 & Nov., 1972 & $9^{\circ} \mathrm{S}-9^{\circ} \mathrm{N}$ & $137^{\circ}-146^{\circ} \mathrm{W}$ & e-P & $\mathrm{i}$ & Swinnerton and Lamontagne $[1974]^{\circ}$ \\
\hline 14 & 29 & Nov. to Dec., 1972 & $14^{\circ} \mathrm{S}-35^{\circ} \mathrm{S}$ & $148^{\circ}-170^{\circ} \mathrm{W}$ & s-P & $\mathrm{i}$ & Swinnerton and Lamontagne $[1974]^{c}$ \\
\hline 15 & 31 & Dec., 1972 & $37^{\circ}-57^{\circ} \mathrm{S}$ & $175^{\circ}-185^{\circ} \mathrm{W}$ & s-P & $\mathrm{i}$ & Swinnerton and Lamontagne $[1974]^{\circ}$ \\
\hline 16 & 14 & Dec., 1972 & $57^{\circ}-77^{\circ} \mathrm{S}$ & $183^{\circ}-187^{\circ} \mathrm{W}$ & s-P & $\mathrm{i}$ & Swimerton and Lamontagne $[1974]^{\mathrm{c}}$ \\
\hline 17 & 21 & June to July, 1973 & $18^{\circ}-25^{\circ} \mathrm{N}$ & $70^{\circ}-86^{\circ} \mathrm{W}$ & $\mathrm{G}, \mathrm{C}, \mathrm{n}-\mathrm{A}$ & $?$ & Swinnerton and Lumontagne [1974] \\
\hline 18 & 55 & Feb. to March, 1974 & $3^{\circ} \mathrm{S}-10^{\circ} \mathrm{N}$ & $80^{\circ}-117^{\circ} \mathrm{W}$ & $e-p$ & i & Lamontagne et al. [1975] $]^{c}$ \\
\hline 19 & 47 & March, 1974 & $12^{\circ}-21^{\circ} \mathrm{N}$ & $122^{\circ}-157^{\circ} \mathrm{W}$ & $n-P$ & $\mathrm{i}$ & Lamontagne et al. [1975]" \\
\hline 20 & 33 & March, 1974 & $8^{\circ} \mathrm{N}-10^{\circ} \mathrm{S}$ & $155^{\circ}-152^{\circ} \mathrm{W}$ & e-P & $\mathrm{i}$ & Lamontagne et al. [1975] ${ }^{c}$ \\
\hline 21 & 43 & March to April, 1974 & $11^{\circ}-17^{\circ} \mathrm{S}$ & $151^{\circ}-126^{\circ} \mathrm{W}$ & s-P & $\mathrm{i}$ & Lamonagne et al. [1975] \\
\hline 22 & 64 & April, 1974 & $9^{\circ} \mathrm{S}-5^{\circ} \mathrm{N}$ & $122^{\circ}-86^{\circ} \mathrm{W}$ & $\mathrm{e}-\mathrm{P}$ & $\mathrm{i}$ & Lamontagne et al. $[1975]^{\circ}$ \\
\hline 23 & 56 & July to Aug., 1977 & $57-63^{\circ} \mathrm{N}$ & $173-178^{\circ} \mathrm{W}$ & $n-P$ & i & Lamonagne [1979] \\
\hline 24 & 40 & July to Aug., 1977 & $60-63^{\circ} \mathrm{N}$ & $168-173^{\circ} \mathrm{W}$ & $n-P$ & $\mathrm{i}$ & Lamontagne [1979] \\
\hline 25 & 20 & Aug., 1974 & $69^{\circ}-71^{\circ} \mathrm{N}$ & $130^{\circ}-139^{\circ} \mathrm{W}$ & s-BS & $\mathrm{i}$ & Macdonald [1976] \\
\hline 26 & 32 & Aug., 1975 & $69^{\circ}-71^{\circ} \mathrm{N}$ & $130^{\circ}-139^{\circ} \mathrm{W}$ & s-BS & $\mathrm{i}$ & Macdonald [1976] \\
\hline 27 & 4 & April, 1985 & $23^{\circ}-0^{\circ} \mathrm{S}$ & $40-50^{\circ} \mathrm{E}$ & $s$ and $\mathrm{e}-\mathrm{IO}$ & c & Bonsang et al. [1988] \\
\hline 28 & 4 & April, 1985 & $2^{\circ}-12^{\circ} \mathrm{N}$ & $49^{\circ}-53^{\circ} \mathrm{E}$ & $\mathrm{n}$ and $\mathrm{e}-\mathrm{IO}$ & c & Bonsang et al. [1988] \\
\hline 29 & 2 & May, 1987 & $24^{\circ} \mathrm{N}$ & $154^{\circ} \mathrm{W}$ & off Hawai & c & Bonsang el al. [1989] \\
\hline 30 & 3 & June, 1987 & $18^{\circ} \mathrm{S}$ & $141^{\circ} \mathrm{W}$ & off Hao & c & Bonsang et al. [1989] \\
\hline 31 & 22 & Sept., 1988 & $8^{\circ}-35^{\circ} \mathrm{N}$ & $30^{\circ} \mathrm{W}$ & $\mathrm{n}-\mathrm{A}$ & $\mathrm{i}$ & Ilass el al. [1992] $]^{\text {}}$ \\
\hline 32 & 14 & Sept., 1988 & $3^{\circ} \mathrm{S}-8^{\circ} \mathrm{N}$ & $30^{\circ} \mathrm{W}$ & $\mathrm{e}-\mathrm{A}$ & $\mathrm{i}$ & Plass et al [1992] \\
\hline 33 & 29 & Sept. to Oct., 1988 & $4^{\circ} \mathrm{S}-30^{\circ} \mathrm{S}$ & $30^{\circ}-35^{\circ} \mathrm{W}$ & $s-A$ & $\hat{\mathrm{i}}$ & Plass et al. $[1992]^{\text {s }}$ \\
\hline 34 & 21 & Aug., 1989 & $44^{\circ}-49^{\circ} \mathrm{N}$ & $3^{\circ}-8^{\circ} \mathrm{W}$ & BoB & $\mathrm{i}$ & Plass-Dilmer el al. [1993] \\
\hline 35 & 15 & Aug., 19898 & $23^{\circ}-38^{\circ} \mathrm{N}$ & $10^{\circ}-17^{\circ} \mathrm{W}$ & $n-A$ & $\mathrm{i}$ & Plass-Diilmer el al. [1993] \\
\hline 36 & 30 & Aug., 1989 & $0^{\circ}-23^{\circ} \mathrm{N}$ & $17^{\circ}-19^{\circ} \mathrm{W}$ & $\mathrm{n}$ and $\mathrm{e}-\mathrm{A}$ & $\mathrm{i}$ & Plass-Dülmer el al. [1993] ${ }^{\mathrm{s}}$ \\
\hline 37 & 46 & Aug. to Sept., 1989 & $0^{\circ}-35^{\circ} \mathrm{S}$ & $20^{\circ}-48^{\circ} \mathrm{W}$ & $s-\Lambda$ & $\mathrm{i}$ & Plass-Diilmer et al. [1993] $]^{\mathrm{s}}$ \\
\hline 38 & 20 & March, 1990 & $10^{\circ} \mathrm{S}-10^{\circ} \mathrm{N}$ & $155^{\circ}-167^{\circ} \mathrm{W}$ & $e-P^{p}$ & $\mathrm{i}$ & Donalue and Prinn $[1993]^{\mathrm{B}}$ \\
\hline
\end{tabular}

ethene do not follow normal distribution (significance level $<0.0001$ ) but follow a lognormal distribution (median $109 \mathrm{pmol} / \mathrm{L}$ and a standard deviation of a factor of 1.9; significance level $0.043 ; \mathrm{n}=838$ ). Also, for the other categorics of data, ethene concentrations follow lognormal distribution but the center of the distribution is shifted to 190 (not specified, standard deviation of factor 1.7), 372 (chemicals added. standard deviation of factor 2.3), and 616 (cylinders, standard deviation of factor 2.3)(all concentrations in picomoles per liter). Ethane distributions are asymmetric and tailing toward higher concentrations. This is observed for all the data categories. The distribution of neither the in situ data nor not specified data fits a lognormal or a normal distribution. e.g. significance level $<0.0001$ for the in situ measurements $(n=814)$. Both the ethenc 
le 2. (continued)

\begin{tabular}{|c|c|c|c|c|c|c|c|}
\hline $\begin{array}{l}\text { Data } \\
\text { Set }\end{array}$ & $\begin{array}{l}\text { Number of } \\
\text { Samples }\end{array}$ & Dille & Latilude & Longitude & Aru: ${ }^{2}$ & Callegory" & Relerence \\
\hline 39 & 23 & April, 1991 & $36^{\circ}-42^{\circ} \mathrm{N}$ & $5^{\circ} \mathrm{E}-6^{\circ} \mathrm{W}$ & MS & $\mathrm{i}$ & Ralte [1993] \\
\hline 40 & 59 & April to May, 1991 & $30^{\circ}-50^{\circ} \mathrm{N}$ & $6^{\circ}-16^{\circ} \mathrm{W}$ & $11-A$ & i & Ratte [1993] \\
\hline 41 & 48 & May, 1991 & $52^{\circ}-58^{\circ} \mathrm{N}$ & $14^{\circ}-16^{\circ} \mathrm{W}$ & $n-\Lambda$ & $\mathrm{i}$ & Ralle [1993] \\
\hline 42 & 14 & May, 1991 & $55^{\circ}-59^{\circ} \mathrm{N}$ & $0^{\circ}-5^{\circ} \mathrm{E}$ & NS & $\mathrm{i}$ & Ratte [1993] \\
\hline 43 & $>100$ & Oct., 1971 & $19^{\circ}-30^{\circ} \mathrm{N}$ & $87^{\circ}-95^{\circ} \mathrm{W}$ & G & $\mathrm{i}$ & Brooks and Sackett [1973] \\
\hline 44 & 1 & Sept., 1968 & $23^{\circ}-29^{\circ} \mathrm{N}$ & $89^{\circ}-95^{\circ} \mathrm{W}$ & $\mathrm{G}$ & a & Franck et al. [1970] \\
\hline
\end{tabular}

\footnotetext{
a Area codes: n, north; e, equatorial; s, south; A, Atlantic; BoB, Bay of Biscay; BS, Beaufort Sea; C, Caribbean; G, Guli of Mexico; IO, Indian Ocean; MS, Mediterranean Sea; NS, North Sea; P, Pacific.

${ }^{b} \mathrm{i}$, in situ; ?, not specified; a, chemicals added to sample; $c$, stripped NMHC stored with purge gas in cylinders.

${ }^{c}$ Only daily averages of up to eight measurements are given.

'Samples were collected in collaboration with W.D. Smith.

'Samples were collected in collaboration with Brooks et al. [1973].

'Samples were collected in collaboration with J. Bunt.

${ }^{8}$ Data tables from Plass [1992].

'Data extracted from the figures by Donahue and Prinn [1993] and N.M. Donahue (personal conmunication, 1991).
}

and ethane concentrations generally exceed $4 \mathrm{pmol} / \mathrm{L}$ which is well above the detection limit of about $1 \mathrm{pmol} / \mathrm{L}$. Thus the steep cutoff observed for ethane toward low concentrations is not ied by analytical limitations.

\subsection{Relations Between Different Hydrocarbons}

Linear relations between different hydrocarbons have been reported by several authors [Lamontagne et al., 1974; Bonsang et al., 1988; Plass et al., 1992]. Figure 5 presents concentration ratios for the various data sets and data categories. While generally fairly constant ratios are observed, some of the ratios ffer substantially with respect to mean ratio and standard deviation. This may be due to real variability, sampling artifacts, large uncertainties at extremely low concentrations, and calibration errors.

Ratios between different alkenes or between different alkanes from in situ data sets (listed in Table 5) are generally identical to the average within a factor of 2 (Figure 5). Ethene-propene ratios are significantly enhanced in data sets with chemicals added. Data sets of the not specified category generally show a larger scatter of the data than the in situ data sets, and ethenepropene ratios are on avcrage higher than in in situ data sets. The data sets of the cylinder category result in alkane ratios similar to the in situ data, alkene ratios show larger scatter, and especially data set 30 differs from the in situ average. Etheneethane ratios are not constant in any of the data entegories. Mean ratios between ethene and cthane of different data sets can differ by more than an order of magnitude.

Thus in situ data gencrally differ in two aspects from other categories of data: absolute concentrations are lower (see section 4.1) and ratios among some of the hydrocarbons, especially the kenes, are more constant. Although some of the non-in situ data sets are comparable to the in situ data sets with respect to these features, in general, the deviations and the scatter in the ratios are higher for non-in situ data. There is no way to decide if these differences are "real" or due to the storage process. However, since data of the non-in situ categories have a principally larger uncertainty due to the additional storage process and the data appear to differ from in situ results, we think it is not appropriate to compile the data of different categories into one database. Thus we will focus on the in situ measurements.

\section{Dissolved NMHC in the Oceans: Geographical Distributions and Parameters Influencing Concentrations}

The following discussions of the distribution of hydrocarbons in seavater are focused on ethene. In some cases, ethane is also considered. Both are the most abundant compounds of the $\mathrm{C}_{2}-\mathrm{C}_{4}$ alkenes and alkanes, respectively, and as discussed in section 4 the concentrations of $\mathrm{C}_{3}$ and $\mathrm{C}_{4}$ hydrocarbons are well related to the $\mathrm{C}_{2}$ hydrocarbons. In the case of acetylene, butanes, and butenes the number of available data is much lower (compare Table 3) and less appropriate to derive representative distributions.

In order to identify those factors which have an impact on NMHC concentrations, possible relations between concentrations and physical or biological parameters will bc tested in a correlation analysis. For this purpose a database is set up.

\subsection{Data for a Global and Seasonal Grid}

From Figure 1 it is apparent that there are regions with fairly dense data coverage (e.g., Gulf of Mexico and the Carribean area) and regions where measurements are scarce or absent (e.g. the eastern Pacific and the southern oceans). A discussion of the distributions of the NMHC concentrations using all original measurements would give too much weight to those regions and 


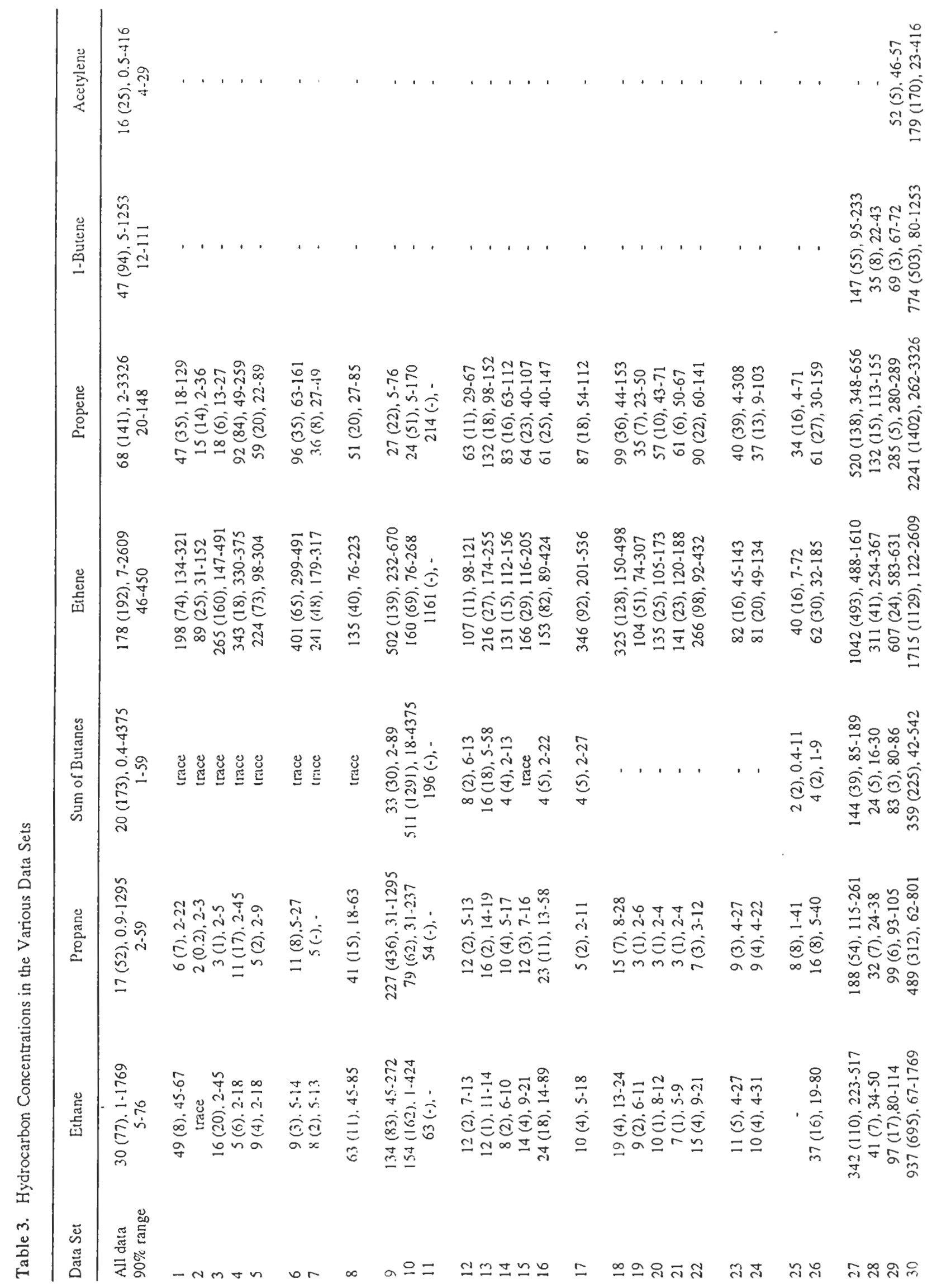




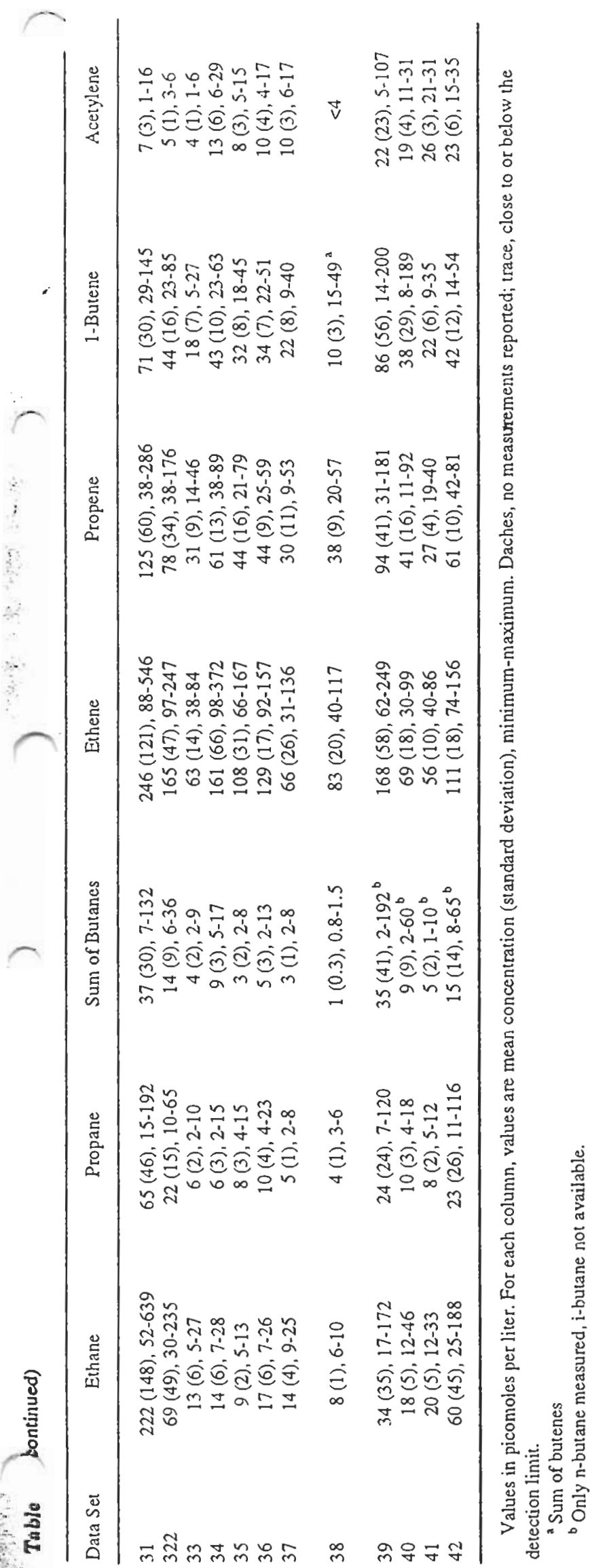

scasons where intensive campaigns with a large number of measurements have been carricd out. On the other hand, a too extreme averaging, e.g., using only the averages of the 42 data sets, may smooth out systematic variations. As a compromise, we decided to average the data geographically for a grid of $10^{\circ}$ longitude $\times 10^{\circ}$ latitude and for a time period of 1 month $\left(10^{\circ} \times 10^{\circ} \times 1\right.$ month). This results in a coverage of about $2 \%$ or 75 of the total of more than 5000 cells with in situ data. If all data categories are considered, 122 cells are covered with data. Besides the scarce data coverage in the southern oceans, the majority of data from northern and southern latitudes higher than $20^{\circ}$ were obtained in summer and only a few in winter (Table 6).

In addition to limitations due to data coverage, concentration averages for particular cells may not be representative. This is obvious for grid cells with scarce data coverage; occasionally, only one measurement exists. The range of naturally occurring variations in the concentrations can be estimated from intensive measurements within a cell, which easily accounts for a factor of 2 and more [e.g., Plass et al., 1992; Swinnerton et al., 1977; Macdonald, 1976].

Such variations are not unexpected since the NMHC concentrations are established by a complex balance of production and loss processes in the surface layer of the ocean which generally is not in a steady state [Plass-Dülmer et al., 1993]. In order to identify the parameters which impact on the production and loss processes a database of parameters was set up according to the grid for concentrations $\left(10^{\circ} \times 10^{\circ} \times 1\right.$ month). Based on our present state of knowledge, the production of NMHC in seawater is strongly influenced by the concentration of dissolved organic carbon (DOC) and the solar insolation [Wilson et al., 1970; Ratte et al., 1993]. As a measure of the solar insolation, we used the global solar radiation at noontime according to an anlytical expression at clear sky conditions reported by Paltridge and Platt [1976] which summarizes their results obtained at Aspendale, Australia. Information about DOC concentrations is still very limited and strongly dependent on the analytical method [Suzuki et al., 1992; Wangersky, 1993]. Global and seasonal distributions of DOC obtained by a single method are, to our knowledge, not yet available. Thus we presently can only refer to potential sources of DOC such as phytoplankton and coastal inputs. Additionally, it has been discussed that phytoplankton activity has an impact on the alkene concentration in seawater [Swinnerton and Lamontagne, 1974; Wilson et al., 1970]. As a measure of phytoplankton activity, we used the chlorophyll $a$ concentrations from monthly or seasonally averaged composites of the Coastal Zone Colour Scanner on board of the Nimbus 7 satellite [Feldman et al, 1989]. Coastal influences were considered by accounting for the distance from the coast. Furthermore, the seawatcr temperature is an important factor in biological and chemical processes and thus was also considered. The temperature of surface seawater was taken from climatological averages [Brown et al., 1989].

The only loss process identified so far is the emission into the atmosphere. It is proportional to the concentration gradient and the transfer velocity. For light alkenes and alkanes the atmospheric concentrations can generally be neglected [Plass et al., 1992], and thus the emissions are proportional to the seawater concentrations. The transfer velocity is calculated according to Liss and Merlivat [1986]. We based the calculation 
Table 4. Concentrations of Light Hydrocarbons in In Situ Measurements Compared to Other Data

\begin{tabular}{|c|c|c|c|c|}
\hline Compound & $\begin{array}{c}\text { In Situ } \\
(12-16,18-26,31-42)^{n}\end{array}$ & $\begin{array}{l}\text { Not Specified } \\
(1-8,17)\end{array}$ & $\begin{array}{c}\text { Chemicals } \Lambda \text { dded } \\
(9-1 !)^{n}\end{array}$ & $\begin{array}{l}\text { Cylinder } \\
(27-30)\end{array}$ \\
\hline \multirow[t]{2}{*}{ Ethanc } & $22(44)$ & $29(27)$ & $84(95)$ & $349(484)$ \\
\hline & $6.3-52(814)$ & $2-75(268)$ & $9-401(44)$ & $35-974(13)$ \\
\hline \multirow{2}{*}{ Propane } & $11(14)$ & $18(19)$ & $78(186)$ & $196(230)$ \\
\hline & $2.3-24(826)$ & $2.0-62(268)$ & $18-273(45)$ & $27-605(13)$ \\
\hline \multirow[t]{2}{*}{ Sum of butanes } & $7.4(12)$ & $2.2(1.6)$ & $184(629)$ & $147(167)$ \\
\hline & $1.1-29(348)$ & $2.0-2.0^{b}(268)$ & $9-357(46)$ & $25-494(13)$ \\
\hline \multirow{2}{*}{ Ethene } & $134(95)$ & $217(112)$ & $562(432)$ & $906(806)$ \\
\hline & $42-358(838)$ & $76-446(268)$ & $99-1161(44)$ & $254-2414(13)$ \\
\hline \multirow[t]{2}{*}{ Propene } & $59(36)$ & $56(32)$ & $113(109)$ & $762(1067)$ \\
\hline & $21-135(834)$ & $22-102(268)$ & $4.5-352(45)$ & $130-3134(13)$ \\
\hline \multirow[t]{2}{*}{ Sum of butenes } & $37(29)$ & - & - & $536(970)$ \\
\hline & $10-95(308)$ & & & $36-2563(13)$ \\
\hline \multirow[t]{2}{*}{ Acetylene } & $14(10)$ & - & - & $128(146)$ \\
\hline & $4.3-29(313)$ & & & $23-416(5)$ \\
\hline
\end{tabular}

\footnotetext{
For each column, values are mean concentration (standard deviation)(pmol/L) $90 \%$ range (pmol/L)(number of measurements)

"In addition to the data sets of Table 2 some miscellaneous samples were considered (from references of Table 2).

${ }^{b}$ More than $90 \%$ of the values at the detection limit of about 2 pmol/L.
}

on frequency distributions of wind velocities from monthly composites of climate atlases [Marine General Staff, 1953; U.S. Navy, 1957] and seawater temperatures. The transfer velocities were determined from the frequency distribution of the wind velocitics by first calculating the transfer velocity for each wind speed at the given temperature and subsequently averaging according to the distribution. This method is more reliable than a calculation of transfer velocities from mean wind velocitics due to the nonlinear relationship between wind and transfer velocities [Liss and Merlivat, 1986].

Values of all the above parameters were determined for all cells for which NMHC measurements exist. However, they generally refer to estimates or climatologic values. These can deviate substantially from real values for individual cells. Variations of a factor of 2 and more for the transfer velocily and the chlorophyll a concentration can be expected.

\subsection{Relations Between NMHC Concentrations and Environmental Parameters}

All the various uncertainties in the potential controlling parameters and NMHC concentrations discussed in the section 5.1 set a considerable limitation to what may be expected from lincar correlations. For the in situ data ( 75 grid points) no significant linear correlations for cthane with any of the parameters exist. Also for ethene no significant positive correlation is observed. But ethene concentrations are significantly anticorrelated with the transfer velocitics $(r=-0.49$; In $>0.29$ is significant on the $1 \%$ level)(Figure 6. solid symbols). Taking all 121 data points (all calcgories), some correlations which are statistically significant are observed. However, they are dominated by the high concentrations measured in the data category cylinder. As an example, Figure 6 shows the ethene concentrations as a function of the transfer velocities. The anticorrelation observed in the in situ data $(r=-0.46)$ is damped $(r=-0.25)$ due to some data of category cylinder and chemicals added which are substantially different from the other data.

Of all parameters considered, the transfer velocities have the largest impact on ethene concentrations. This allows us to generalize previous results for investigations in the Atlantic [Plass et al, 1992; Plass-Dülmer et al,, 1993]. Emissions into the atmosphere were found to be the major loss process for alkenes and, in some cases, also for alkanes. However, a correlation coefficient of $r=-0.49$, though significant, can only explain $24 \%$ of the variance. Thus apart from the substantial limitations discussed above, it appears that further parameters are of importance for the balance of light NMHC in seawater, especially for the production process. In a first and rough approximation, the atmospheric emission rates of alkenes can be assumed to be the only loss process and thus should be balanced by production. In this context, the concentrations are a less appropriate measure for the production rates than the emission rates. Consequently, high alkene concentrations can be due to both high alkene production rates and/or low transfer velocities.

Figure 7 gives an example showing such a situation. The concentrations of ethene measured in situ in the equatorial Pacific $\left(30^{\circ} \mathrm{S}-30^{\circ} \mathrm{N}\right)$ during various investigations clearly decrease toward higher western longitude (Figure 7a). This feature could, at first sight, be interpreted as being due in decreasing ethene proxluction with increasing distance from the upwelling regions off the American coast. In consequence, this would suggest a relation between hydrocarbon concentrations and biological productivity. However, for the cthene emission rates no such trend with longitude exists (Figure $7 \mathrm{~b}$ ). On average, the transfer rates exhibit a reverse trend will longitude compared to the concentrations: They increase due to higher wind velocities where the concentrations decrease. The product of both (the emission rates) is unchanged. Thus the decrease in the ethene concentrations toward higher western longitudes: (Figure 7a) is explained in the most simple manner by fairly 

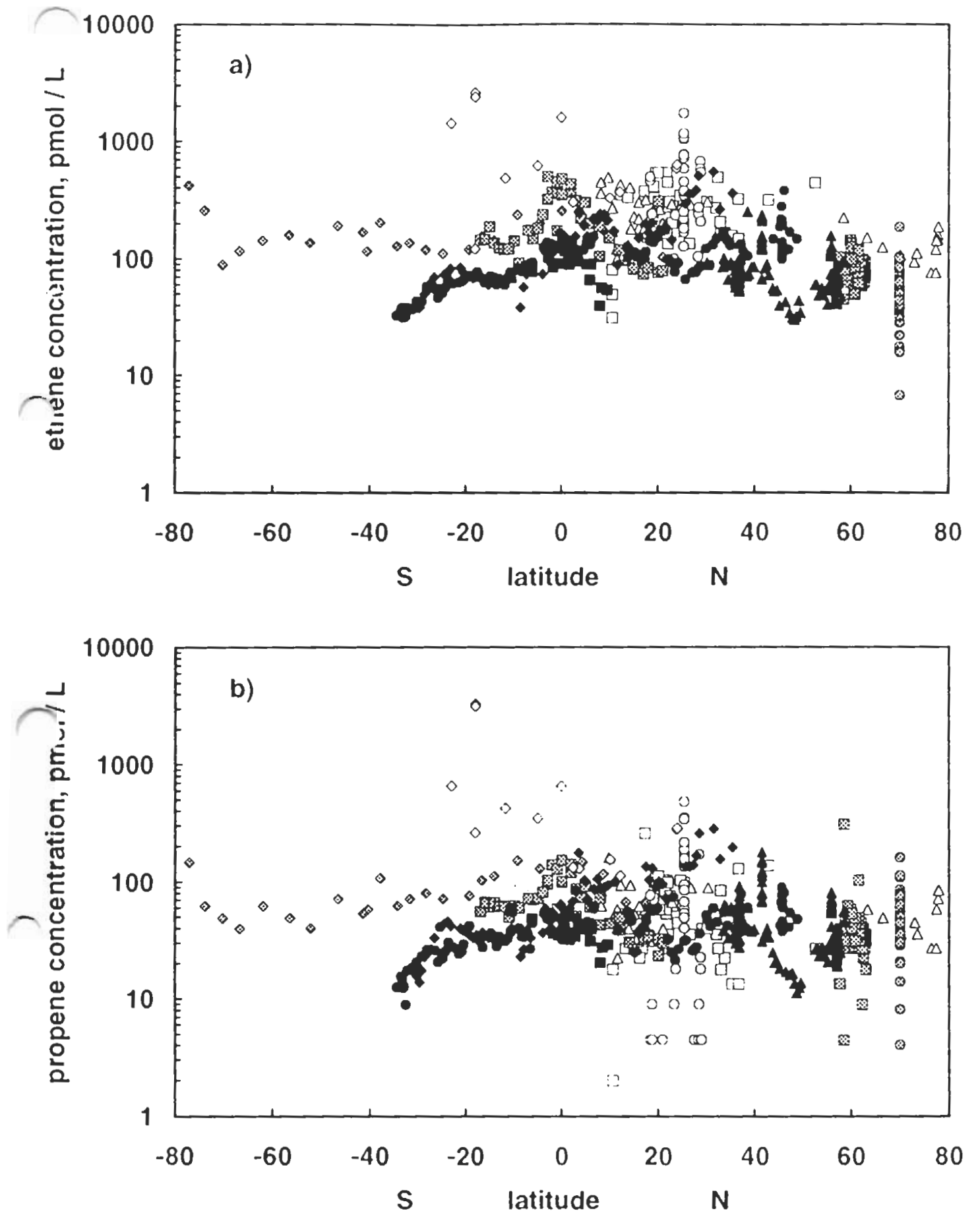

Figure 2. The latitudinal distribution of (a) ethene and (b) propene concentrations in surface seawater; symbols as in Figure 1 (solid and shaded symbols are used for in situ measurements; open symbols are used for other dati categorics). Each point represents a single measurement or a daily arerage. Concentrations reported as "trace" were given the value of the detection limit in the reference.

constant proluction and increasing transler rates. In this context,

ndications for links with biology remain.

nother feature often discussed in the literature is the observation of enhanced concentrations in the region of the equatorial current compared to higher latitudes, which is generally assumed to be is consequence of high primary productivity in the equatorial upwelling region [Lonnontagne et al., 1974, 1975; Ehhalt and Rudolph, 1984]. Figure 8 compares cthene concentrations and emissions obtained in six different (ransects of the equator. The line represents the results by Lamontagne ef al. [1974] which show a broad concentration maximum wilh about a fiactor of 2 higher concentrations between 

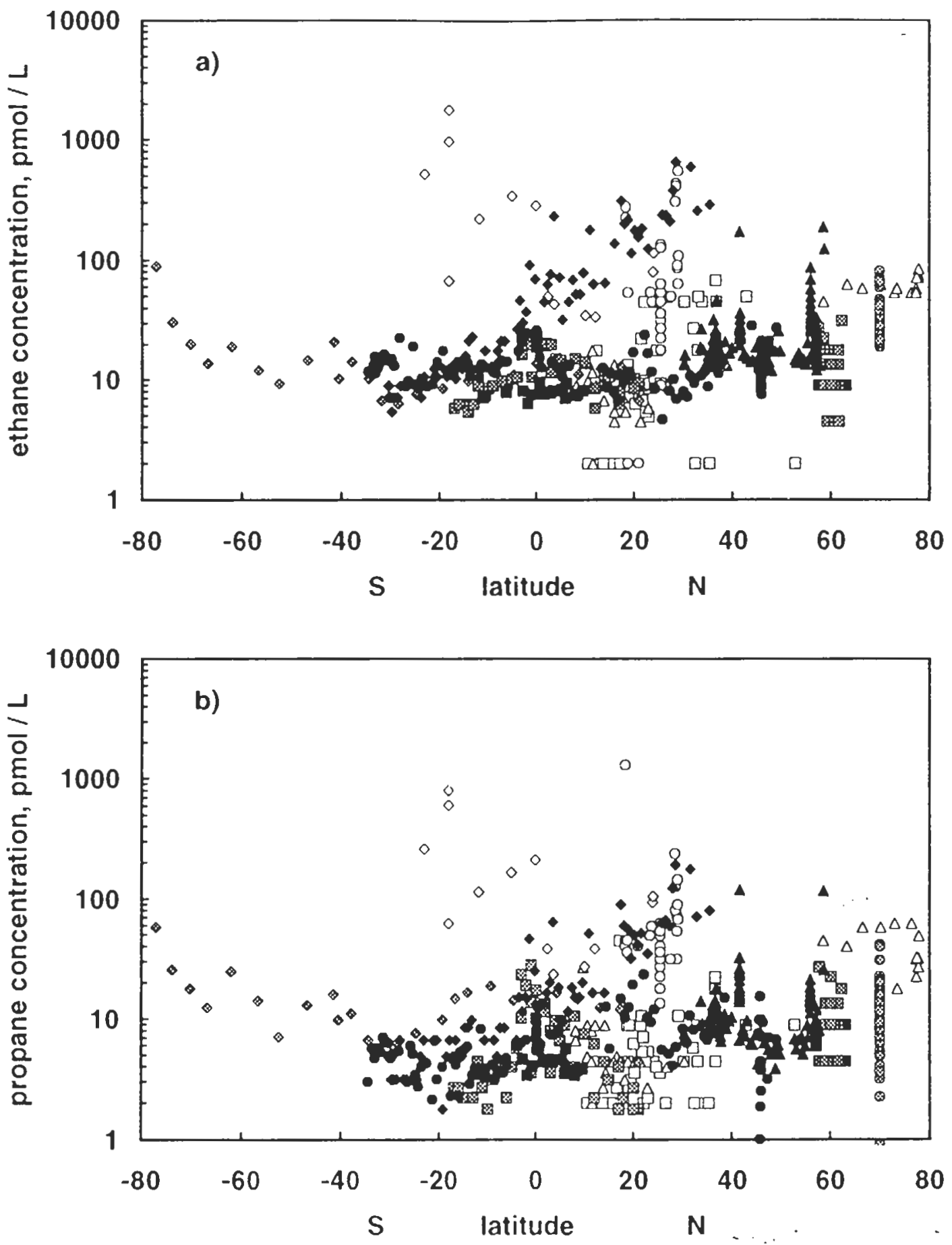

Figure 3. The latitudinal distribution of (a) ethane and (b) propane concentrations in surface scawater; symbols as in Figure 1.

$10^{\circ} \mathrm{N}$ and $10^{\circ} \mathrm{S}$. Some of the other transects show similar but less pronounced maxima; others do not. Again, there is no indication for systematically enhanced emissions near the equator. Low transfer velocitics in the center of the Intertropical Convergence Zone (ITCZ) are the most probable reason for enhanced concentrations in this region.
Scasonal changes can be discussed for same or nearby grids in different months. Since in tropical regions the climatic changes with season are less pronounced we will focus on extratropical areas. The database only contains two such areas. Figure 9 shows the ethene concentrations and the calculated emission rates for the months of measurements. However, the 
ethene
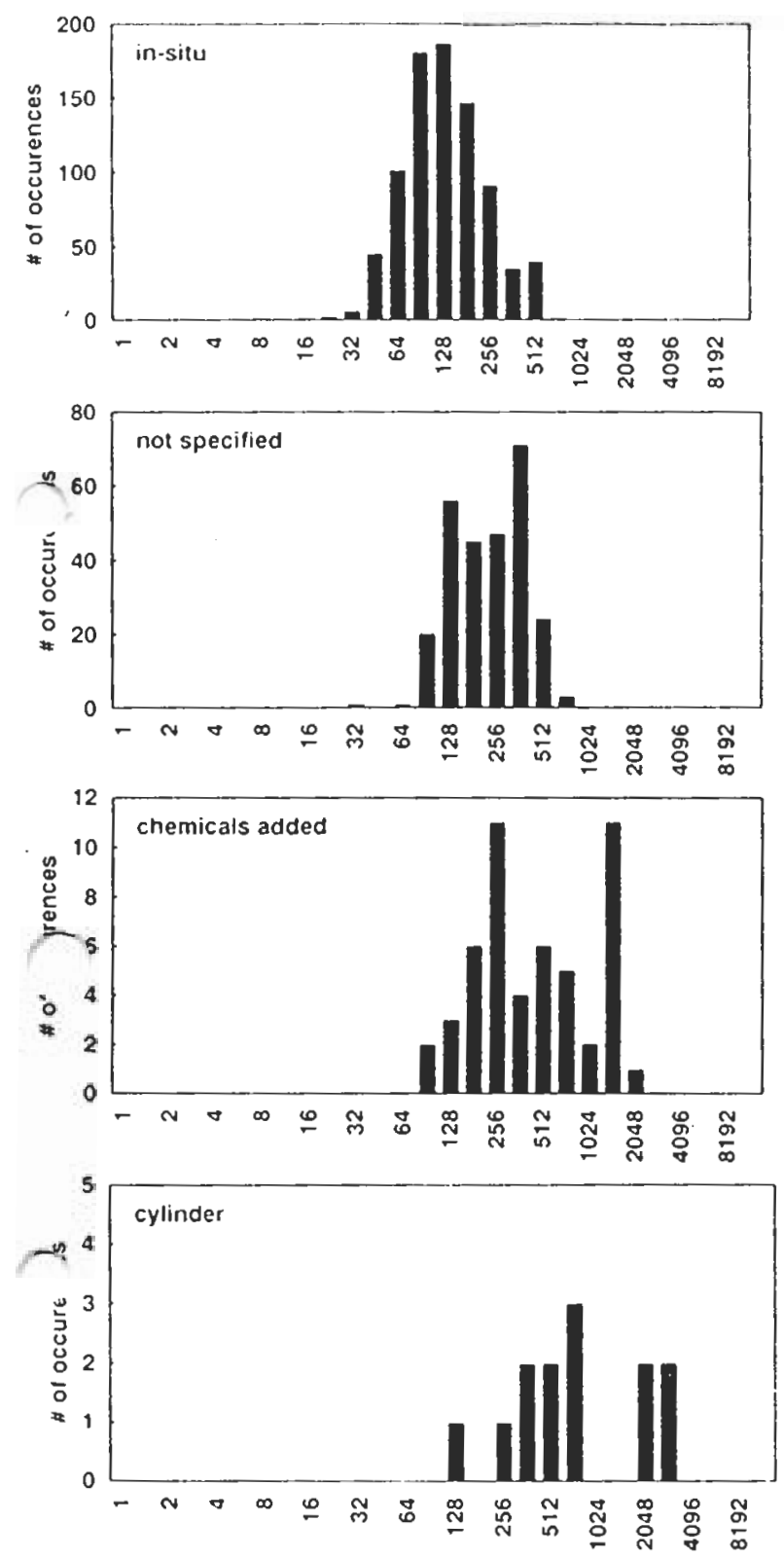

ethene concentration. pmol. L ethane
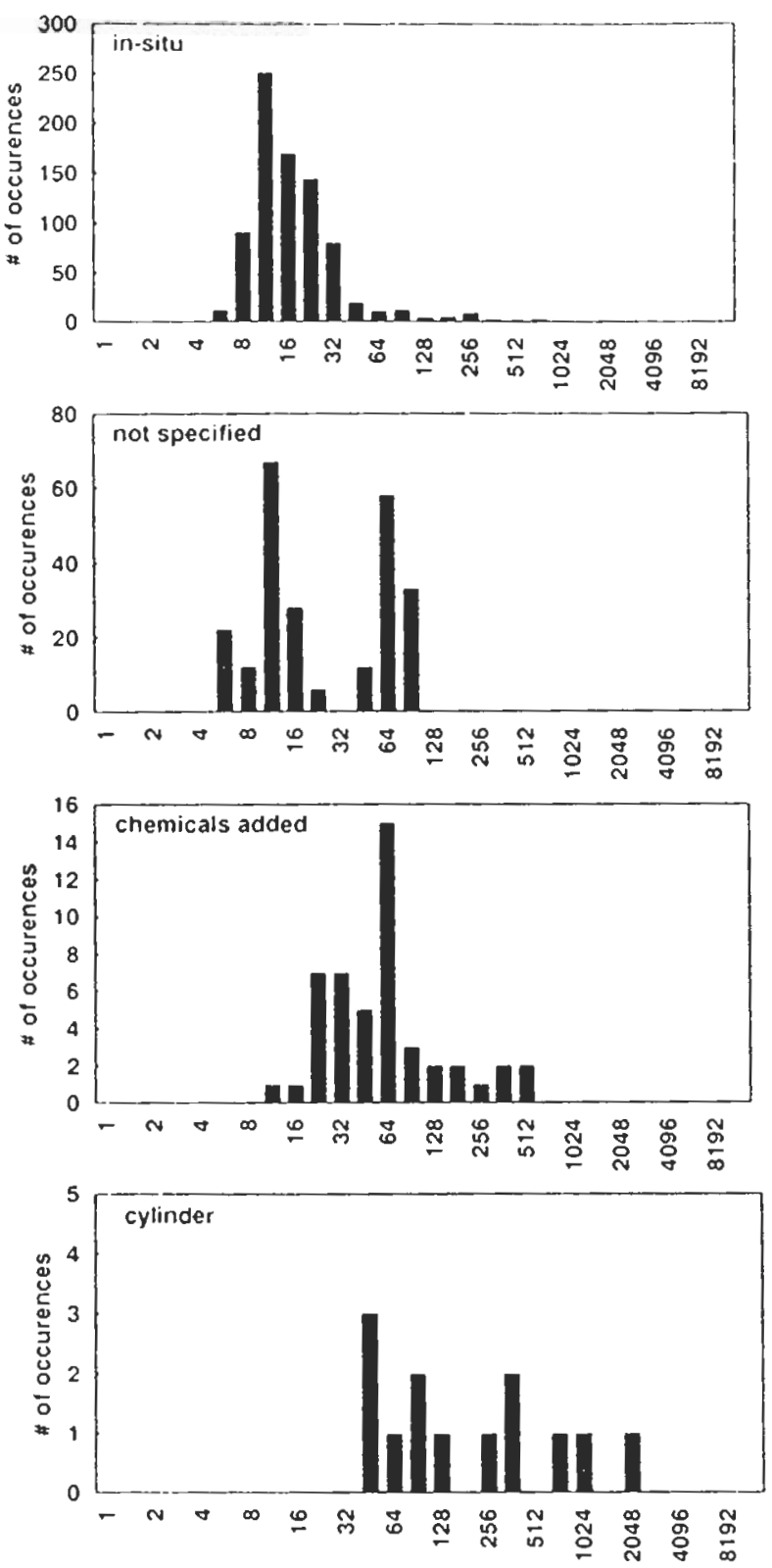

ethane concentration. pmol : $L$

Figure 4. Histograms of the concentrations of ethene and ethane.

situation is complicated since only for one area (Figure 9b) can in situ data be conipared, Data with chemicals added (Figure 9a) were considered here since they comprose the most extensive study of this kind by Swinnerton et al. [1977] for the periol Truary to June in the Gulf Stream off Miami (Figure 9a).

thermore, the samples with sodium azide added were analyzed within a periol of 2 hours [Swinnerton $c t$ al., 1977] and are possibly reliable. Samples taken in the coastal environment [Swinnerton et al., 1977] were not considered here becausc apart from climatological influences, local contaminations or interactions between water and bottom might interfere. The concentrations are constant for February to March and increase by more than a factor of 2 in May and June. The transfer velocities show an opposite trend so that the emission rates are unchanged for the whole periol. However, owing to the use of climatologic data for the calculation of the transfer velocitics, the emission rates are substantially uncertain. For a region in the Allantic (Figure 9b), enhanced ethene concentrations and 

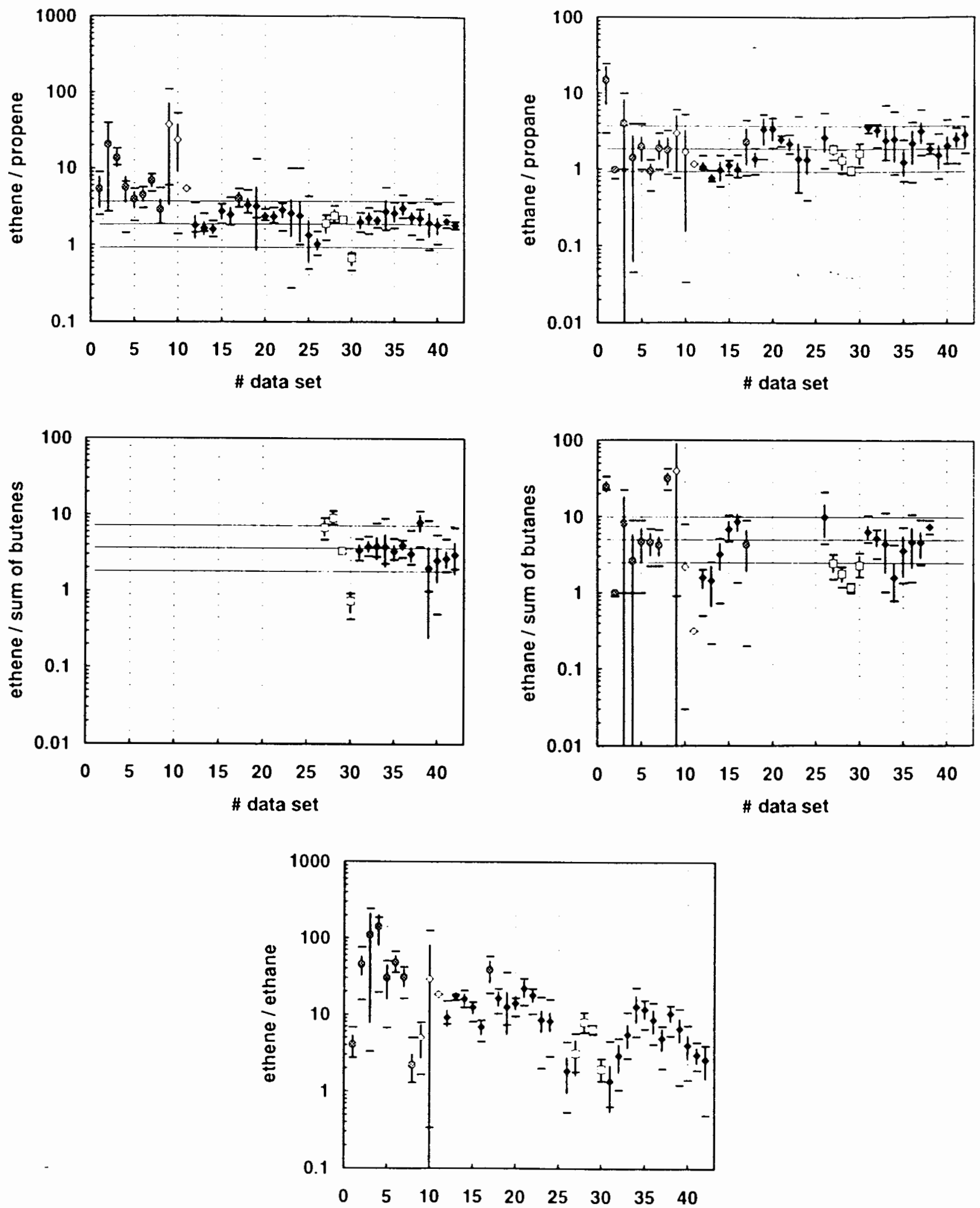

Figure 5. Concentration ratios of different hydrocarbons in the various data sets: averages (solid diamonds, in situ; shaded circles, not specified; open diamonds, chemicals added; open squares, stripped hydrocarbons stored in cylinders), standard deviations (bars), and upper and lower limits (dashes) are indicated. Mean concentration ratios of in situ data (thick line, see text) and a range of a factor of 2 above and below the mean are indicated by the thin lines. 
Table 5. Ratios Between the Concentrations of Light Alkenes and Alkanes

\begin{tabular}{|c|c|c|c|}
\hline \multirow[t]{2}{*}{ Ratio of compounds } & \multirow{2}{*}{$\begin{array}{c}\text { In Situ Data } \\
\text { Average (Standard Deviation) }\end{array}$} & \multicolumn{2}{|c|}{ Percen of Ratios" Within a Factor of 2 of Average (Number of Ratios) } \\
\hline & & In Silu Daia & All Data \\
\hline Ethene/propene & $2.3(0.5)$ & $94(834)$ & $85(1166)$ \\
\hline Ethene/1-butens & $3.6(1.4)$ & $84(303)$ & $82(316)$ \\
\hline Ethane/propane & $2.1(0.9)$ & $76(779)$ & $74(1075)$ \\
\hline Ethane/sum of butanes & $4.7(1.6)$ & $57(213)$ & $49(276)$ \\
\hline
\end{tabular}

${ }^{a}$ Ratios from measurements above the detection limit are used.

emissions in the summer compared to spring are observed. However, these measurements were generally not made in the same $10^{\circ} \times 10^{\circ}$ grid cell, a factor which adds substantial uncertainty to the trend. Thus the available data from same or nearby areas do not allow identification of seasonal trends in the ethene emission rates. The ethene emission rates from all in situ data (Figure 10) separated according to seasons show no indications for systematic trends with season at given latitude bands.

According to the balance of NMHC in the mixed layer, correlations between the parameters suspected to play a role in the NMHC production and the emission rates seem more promising than correlations between these parameters and concentrations. However, single and multiple parameter linear correlations of ethene and ethane emission rates (all data categories) vere generally poor. For the in situ data the following correlations exceeding the $1 \%$ significance level ( $f H>0.29)$ were found. The ethene emissions are anticorrelated with increasing northern and southern latitude $(r=-0,45)$. The ethane emissions are correlated with the longitude $(r=0.30$. western longitudes negative). On average, the ethane emissions (in situ) from the Atlantic $\left(0.60 \pm 0.77 \times 10^{8}\right.$ molecules $\left.\mathrm{cm}^{-2} \mathrm{~s}^{-1}\right)$ exceed those of the Pacific $\left(0.15 \pm 0.12 \times 10^{8}\right.$ molecules $\left.\mathrm{cm}^{-2} \mathrm{~s}^{-1}\right)$ by a factor of 4 , a difference which was not found for alkenes. In the early studies by Brooks and Sacketl [1973] and Swinnerton and Lamontagne [1974] a clear correlation between oil pollution and abundance of alkanes was reported. Thus higher alkane emissions from the Atlantic are compatible with a larger degree of oil pollution in the Atlantic than in the Pacific. However. an attempt to associate enhanced alkane concentrations with major oil spills (data for 1984 to 1988 by courtesy of the International Maritime Organization, London) was not successful.

\section{Global NMHC Emissions From the Oceans}

Based on the ethene and ethane emission rates of the $10^{\circ} \times 10^{\circ} \times 1$ month grid, average emissions can be calculated. Ethene and ethane emissions are extrapolated to the global ocean. This is done in Table 7 based on the in situ data, all data, and an upper limit for $90 \%$ of all data. Additionally, the standard deviations of the emissions based on the in situ data are given. The emissions of $\mathrm{C}_{3}$ and $\mathrm{C}_{4}$ hydrocarbon are scaled to the $\mathrm{C}_{2}$ emissions using the ratios defined in section 4.2. This method is preferred to a direct calculation from the data since the data coverage and accuracy are not as good for the $C_{3}$ and $C_{4}$ hydrocarbons as for ethene and ethane. The correction of the transfer rates for the various NMHC basically considers the different molar volumes in the calculation of the diffusion constants and is described elsewhere [Plass-Düliner et al., 1993].

The oceanic emissions of light NMHC from in situ data sum to $2.1 \times 10^{12} \mathrm{~g} / \mathrm{yr}$ with $1.8 \times 10^{12} \mathrm{~g} / \mathrm{yr}$ or $85 \%$ due to alkene emissions (Table 7). Ethene alone contributes about $40 \%$ to the total emission. Compared to these numbers, oceanic emissions based on all data are higher by a factor of about 2 and the $90 \%$ upper limits is higher by factors between 2.5 and 3.5 (Table 7). In total, the $90 \%$ upper limit gives a value of $5.5 \times 10^{12} \mathrm{~g} / \mathrm{yr}$. This level may be interpreted as an estimate of the upper limit of ceanic emissions based on the available data. The calculated oceanic cmissions are on the low side of previous estimates (e.g., $50 \times 10^{12} \mathrm{~g} / \mathrm{yr}$ by Bonsang et al. [1988], $21 \times 10^{12} \mathrm{~g} / \mathrm{yr}$ by Ehhall and Rudolph [1984], and $2.9 \times 10^{12} \mathrm{~g} / \mathrm{yr}$ for ethene alone by Savada and Totsuka [1986]; for more details, compare PlassDiilmer et al. (1993]). The emission estimates presented here are still substantially uncertain because the temporal and spatial

Table 6. Regional and Seasonal Corerage of the $10^{\circ} \times 10^{\circ} \times 1$ Month Grid With In Situ NMHC Mcasurements

\begin{tabular}{lcccc}
\hline Latilude Range & Number of Grid Cells \\
\hline & Nov,-Jan. & Feb.-April & May-July & Aug-Oct. \\
\hline$<20^{\circ} \mathrm{S}$ & 10 & 0 & 0 & 5 \\
$20^{\circ} \mathrm{S}-20^{\circ} \mathrm{N}$ & 5 & 24 & 0 & 10 \\
$>20^{\circ} \mathrm{N}$ & 1 & 6 & 4 & 10 \\
\hline
\end{tabular}




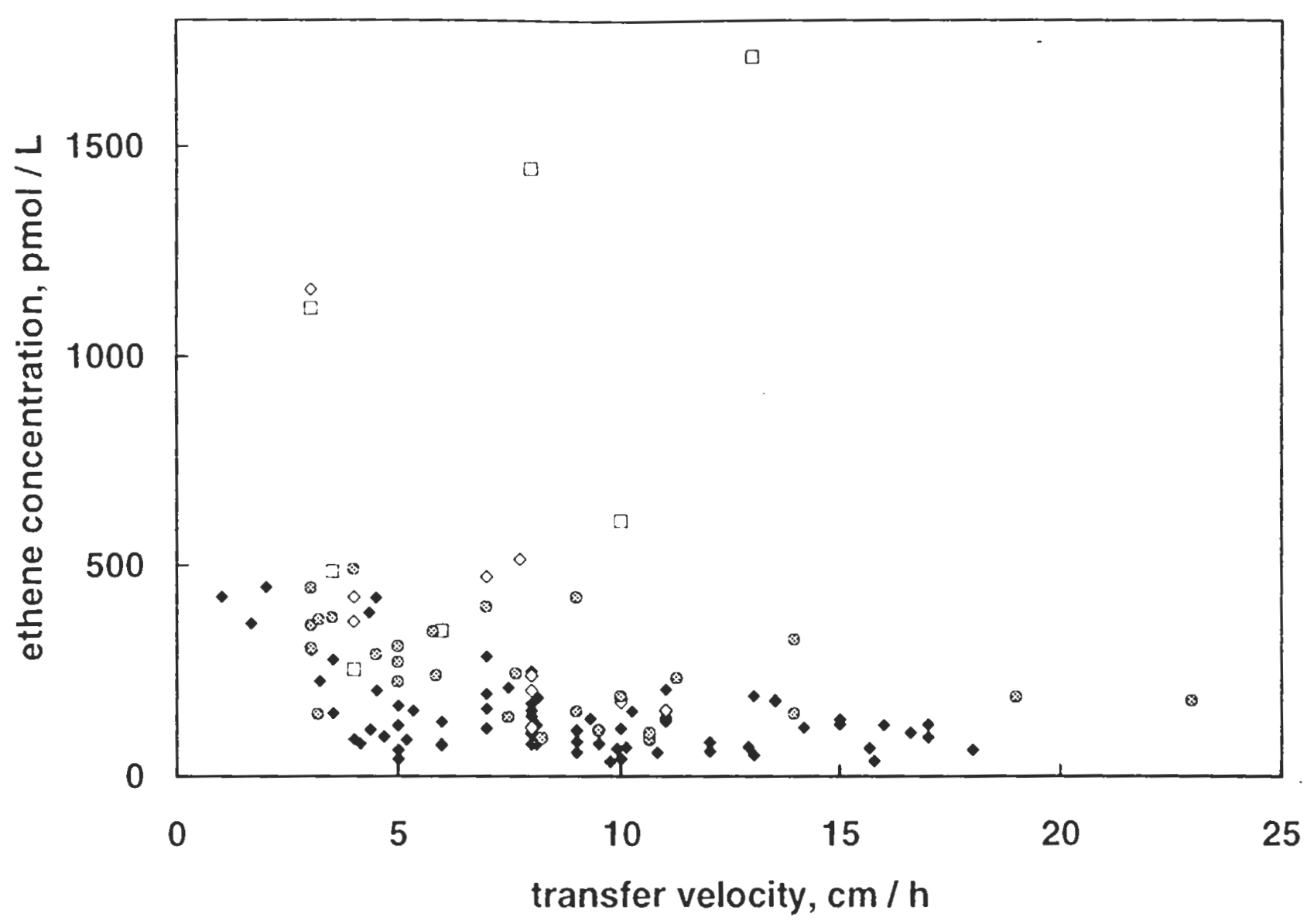

Figure 6. Ethene concentration $\left(10^{\circ} \times 10^{\circ} \times 1\right.$ month database) as a function of the transfer velocity (solid diamonds, in situ; shaded circles, not specified; open diamonds, chemicals added; open squares, stripped hydrocarbons stored in cylinders).

variations of the concentration fields are poorly defined by the existing data and the transfer rates are only climatologic averages. However, the database is substantially larger than in previous estimates and thus, the numbers given in Table 7 are probably the most reliable global oceanic emission estimate so fir.

Acetylene emissions can not be calculated from the concentrations in the seawater alone since for acetylene ocean and atmosphere are close to equilibrium [Plass et al., 1992]. The cialculation of oceanic emission or uptake rates thus would require the knowledge of the atmospheric acetylene concentrations which do not exist for most of the lyydrocarbon measurements in seawater. However. an upper limit of acetylene emissions can be given by the ethane emission rate. The concentrations in seawater (section 4.1) are lower for acetylente, and ethane is larger supersaturated in seawater compared to atmosphere than acetylene Plass et al., 1992; Plass-Diilmer et al., 1993; Kanakidon et al.. 1988]. The upper limit of oceanic acetylene emissions of $0.16-0.54 \times 10^{12} \mathrm{~g} / \mathrm{yr}$ is on the low side of a previous estimate of $0.2-1.4 \times 10^{12} \mathrm{~g} / \mathrm{yr}$ by $K$ anakidon et al. [1988].

\section{Conclusions}

An extensive database for NMHC concentrations in seavater has been compiled using all measurements $(>1000)$ which have been reported to our knowledge. In most investigations the water samples were measured in situ on board the ship. However, in some investigations, chemicals were added to the water samples; in others the extracted gases were stored with the purge gas in cylinders until analysis in the laboratory on land. The results of these investigations deviate from the in situ measurements in either or botl of the following aspects: The concentration ration between different NMHC and their absolute levels which aro generally ligher for non-in situ measurements. However, sinco no intercomparisons among the methods have been performed. we cannot definitely ascribe the cause of the deviation to the methods used. Nevertheless, we think that all results not obtained by in situ measurements must be treated with great caution. We therefore focused on the in situ data.

Ethene is the most abundan of the $\mathrm{C}_{2}-\mathrm{C}_{4}$ hydrocarbons with average concentrations for the in situ data of $134 \mathrm{pmol} / \mathrm{L}$. it range of variation between 7 and 550 mol/L, and $90 \%$ of thi 

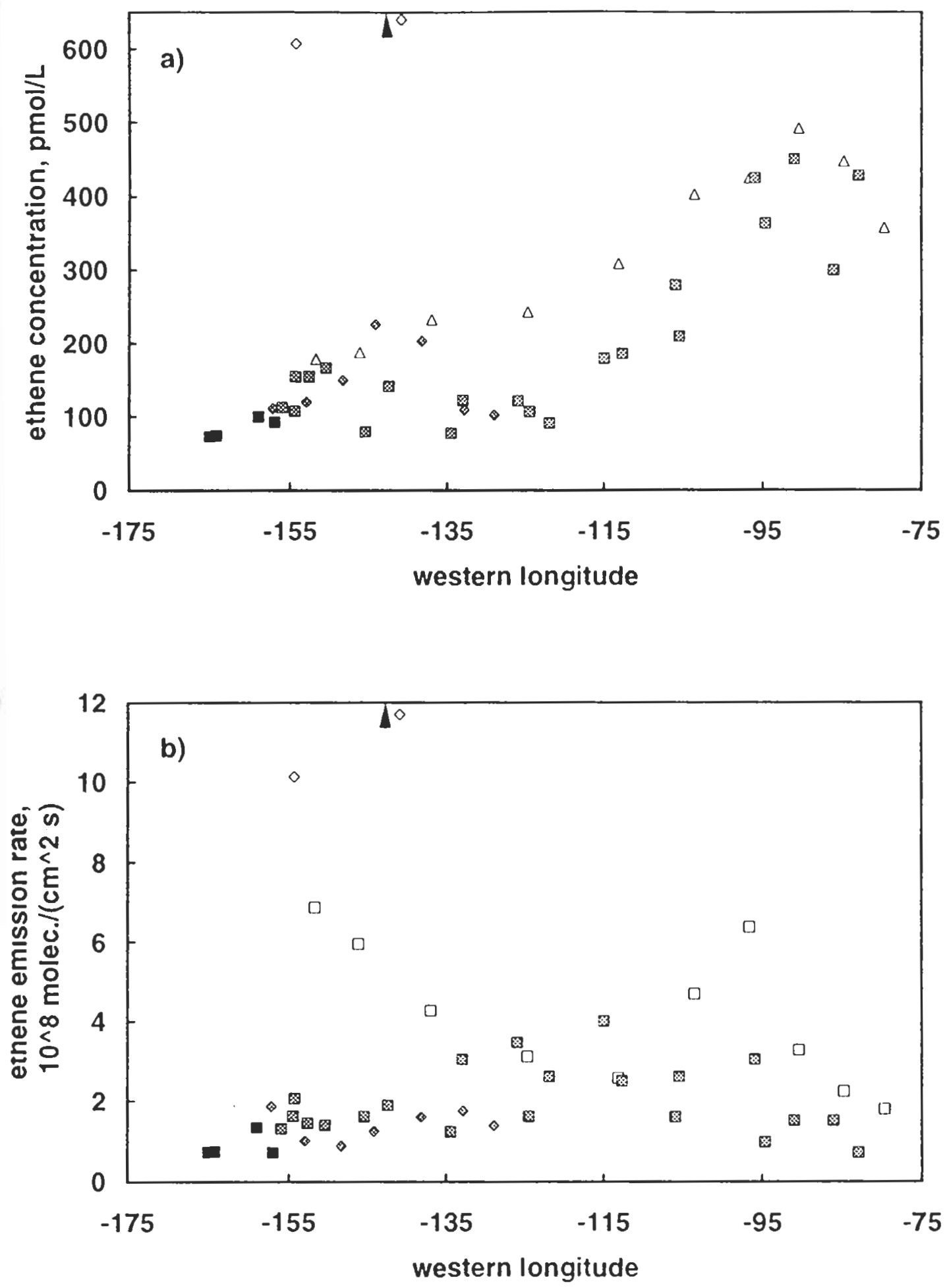

Figure 7. (a) Ethene concentrations and (b) emission rates versus the western longitude for a region of the equatorial Pacific $\left(30^{\circ} \mathrm{S}-30^{\circ} \mathrm{N}\right)$; symbols as in Figure 1: shaded diamonds, 12-16, 1972, and Swinnerton and Lamontagne [1974]; shaded squares, 18-22, 1974, and Lamontagne et al. [1975]; solid squares, 38, 1990, and Donahue and Prinn [1993]; open triangles, 6-7, 1971, and Swinnerton and Lamontagne [1974]; open diamoncls, 29-30, 1987, and Bonsang et al. [ 1989] (data point corresponding to set 30 at $141^{\circ} \mathrm{W}$ is out of range of Figure 7: $1715 \mathrm{pmol} / \mathrm{L}, 37 \times 10^{8}$ molecules $\mathrm{cm}^{-2} \mathrm{~s}^{-1}$ ). 

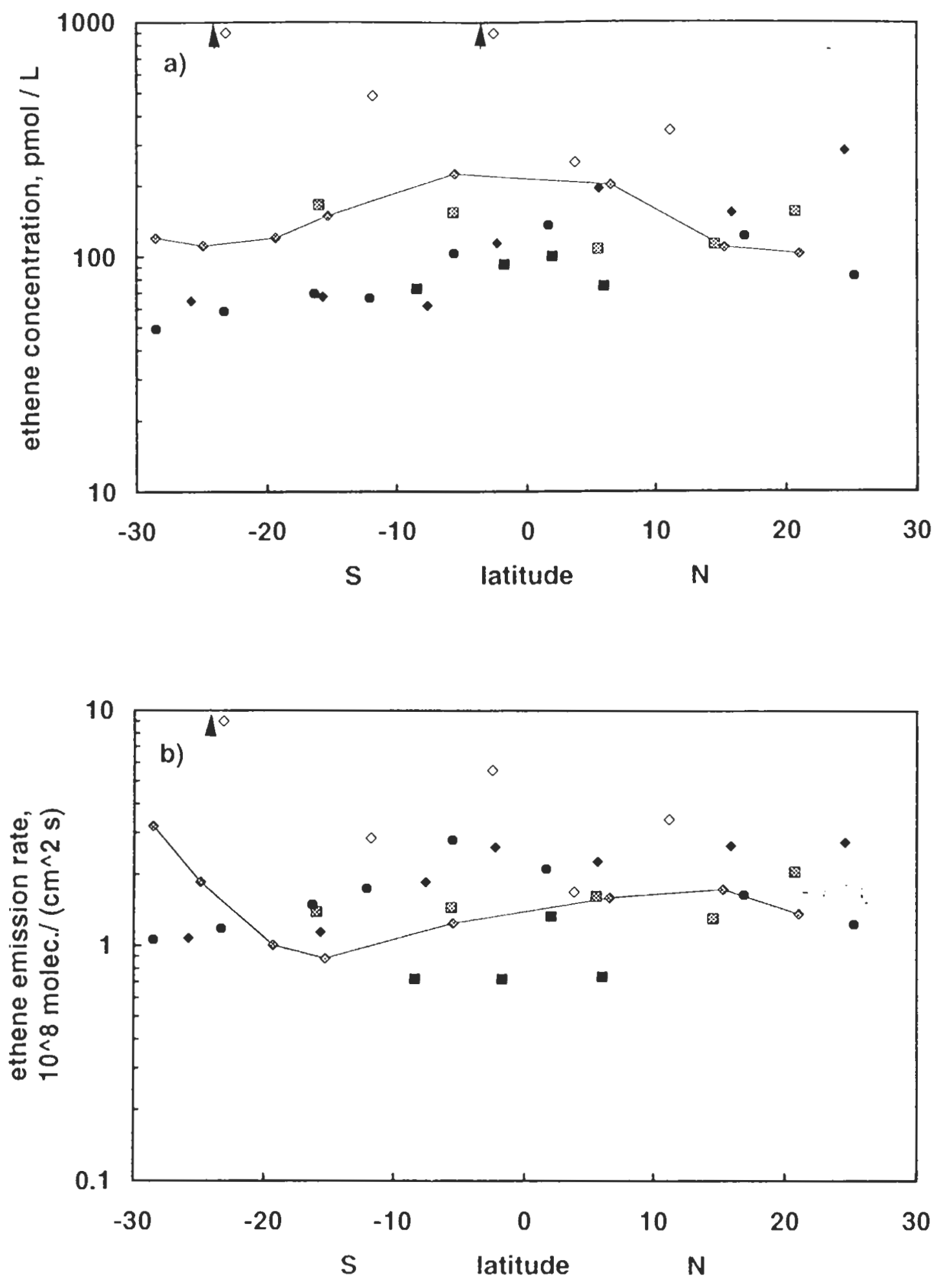

Figure 8. (a) Ethene concentrations and (b) emission rates versus the latitude for six ecpuator transections; symbols ats in Figure 1: Shaded diamonds and line, 12-14, 1972, and Swinnerton and Lamontagne [1974]: shaded squares, 19-21. 1974, and Lamontagne et al. [1975]; solid diamonds, 31-33, 1988, and Plass et al. [1992]: solid circles, 35-37, 1989, and Plass-Diilmer et al. [1993]; solid squares, 38, 1990, and Donahue and Prinn [1993]; open diamonds, 27-28, 1985. and Bonsang et al. [1988](values out of range al $23^{2} \mathrm{~S}, 1449 \mathrm{pmol} / \mathrm{L}$, and $19 \times 10^{8}$ molecules $\mathrm{cm}^{-2} \mathrm{~s}^{-1}$; at $2^{2} \mathrm{~S}, 1116 \mathrm{pmol} / \mathrm{L}$ ). 

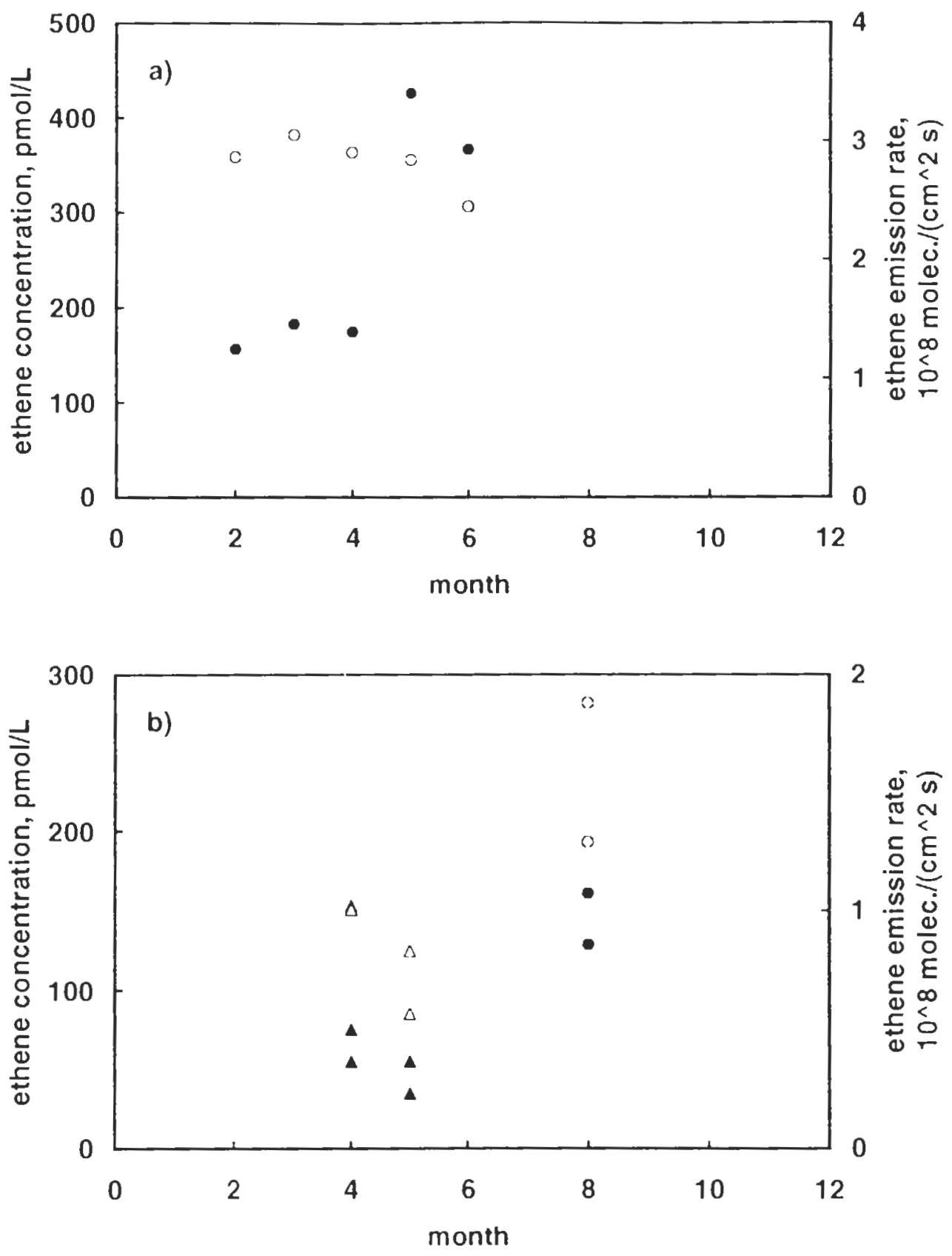

Figure 9. Seasonal changes of ethene concentrations (solid symbols) and emission rates (open symbols) at three locations: (a) Gulf Stream off Miami $\left(25^{\circ} \mathrm{N}, 79^{\circ} \mathrm{W}\right.$ ), Swinnerton et al. [1977]; (b) Atlantic area off west Africa and west Europe $\left(33^{\circ}-53^{\circ} \mathrm{N}, 5^{\circ}-18^{\circ} \mathrm{W}\right)$, circles. Plass-Diilmer et al. [1993], and triangles, Ratte [1993].

data falls between about 40 and $350 \mathrm{pmol} / \mathrm{L}$. The cthenc, propene, and butene concentrations follow lognormal distributions; alkane concentrations neither fit a normal nor a lognormal distribution. As already reperted for small data sets, some of the NMHC concentrations are found in nearly constant ratios: Propenc and butenes follow the concentrations of ethene at lower levels. The same is observed for ethane and the $\mathrm{C}_{3}-\mathrm{C}_{4}$ alkanes. Thus ethene and ethane can be taken as "lead substances" for the light alkenes and alkanes, respectively.
Ethene especially plays a predominant role, since it contributes more than $40 \%$ to the total concentrations of dissolved $C_{2}-C_{4}$ hydrocarbons.

Lincar correlations were tested in order to better understand the production and loss mechanisins of NMHC in seawater. Alkene concentrations. were found to be significantly anticorrelated with the transfer velocities for sea-air exchange. No significant correlations of alkene concentrations were observed with irradiation, water temperature, latitude, 


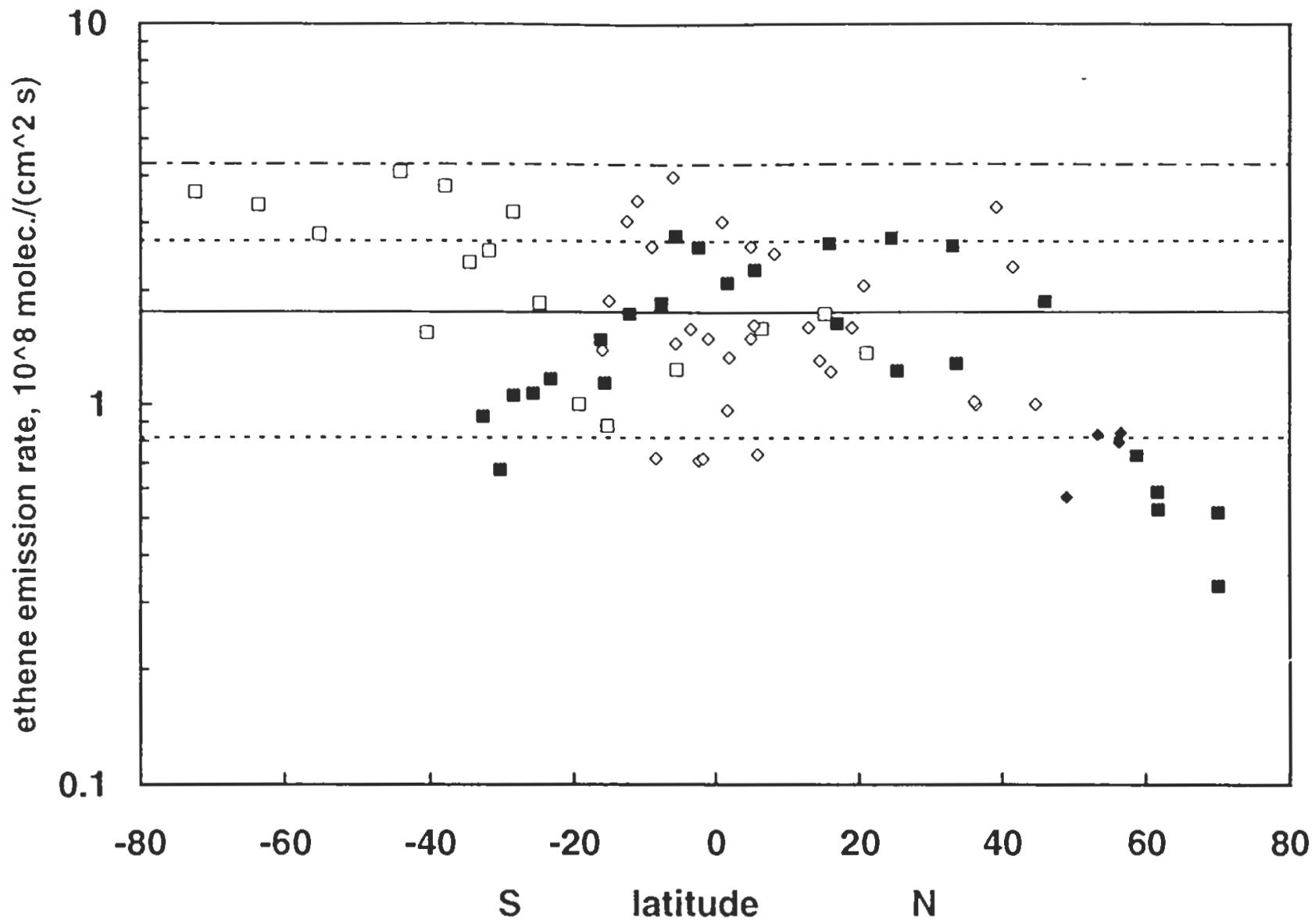

Figure 10. Ethene emission rates as a function of latitude (based on in situ data of the $10^{\circ} \times 10^{\circ} \times 1$ month grid), different seasons are indicated by the symbols: open squares. November-January; open diamonds, February-April: closed diamonds, May-July; closed squares, August-October; the solid line gives the mean emission of $1.8 \times 10^{8}$ molecules $\mathrm{cm}^{-2} \mathrm{~s}^{-1}$, the dotted lines give the range of the standard cleviation of $0.9 \times 10^{8}$ molecules $\mathrm{cm}^{-2} \mathrm{~s}^{-1}$, and the dash-dotted line gives the $90 \%$ upper limit of all data of $4.3 \times 10^{8}$ molecules $\mathrm{cm}^{-2} \mathrm{~s}^{-1}$.

Table 7. Global NMHC Emiscions From the Oceans

\begin{tabular}{|c|c|c|c|c|}
\hline Compound & In Siru & $\sigma^{2}$ & All Data & $90 \%$ Upper Limil" \\
\hline Fthene & 0.89 & 0.47 & 1.40 & 2.17 \\
\hline Ppropence & 0.52 & 0.30 & 0.82 & 1.27 \\
\hline Sum of hutene: & 0.40 & 0.21 & 0.63 & 0.97 \\
\hline$\sum C_{-}-C_{d}:$ d kicnes & 1.80 & & 2.85 & $4.4 !$ \\
\hline I:thane & 0.16 & 0.26 & 0.32 & 0.54 \\
\hline Propane & 0.10 & 0.11 & 0.20 & 0.35 \\
\hline Sum of hutanes & 0.06 & 0.09 & 0.11 & 0.19 \\
\hline$\sum C_{-}-C_{4}$ : ilkinnes & 0.32 & & 0.63 & 1.07 \\
\hline$\sum C_{-}-C_{3}$ hydrocoutons & 2.13 & & 3.48 & 5.48 \\
\hline
\end{tabular}

Values in $10^{12} \mathrm{~g} / \mathrm{yr}$.

a Standard deviations of in-silu data.

" Upper limil of 90\% of all data. 
hlorophyll a concentration, and the proximity to coastlines. fowever, results of this correlation analysis are restricted due to the limited data coverage and the use of climatological values for the parameters and not those prevailing during the measurements. Finally, DOC concentrations which are believed to determine the alkenc production [Wilson et al., 1970; Ratle et al., 1993] are not available. So far, the only parameter identified to have an impact on the alkene concentrations is the transfer rate. This implies that high alkene concentrations do not necessarily indicate high emission rates, as has been widely ossumed in the past. For example, enhanced concentrations at the equator or close to coastlines have been ascribed to large alkene production rates as a follow of the high primary productivity in these regions. However, transfer velocities are reduced in these areas and can consistently explain the enhanced concentrations without the need of higher alkene production rates. Thus no indications for a direct link between alkene production and primary productivity exist. Also, seasonal changes of alkene emission rates cannot be identified from the data.

A different situation exists for alkane concentrations. Here, no significant correlations with any of the parameters are observed. It is surprising that no anticorrelation with the transfer velocity is observed since emissions are a loss mechanism for all hydrocarbons. This may be due to either a very inhomogenous distribution of the alkane production or high internal turnover rates in the mixed layer of the ocean with dominant loss mechanisms other than emissions to the atmosphere.

The calculation of global oceanic cmission rates remains the subject of substantial uncertainty even though the number of available data is large. This is mainly due to the scarce spatial and temporal data coverage of about $2 \%$. However, an estimate utilizing the database compiled here is probably more reliable than some of the previous estimates. For the $\mathrm{C}_{2}-\mathrm{C}_{4}$ hydrocarbons, emissions based on in situ data sum up to $2.1 \times 10^{12} \mathrm{~g} / \mathrm{yt}$, with ethene alone contributing $40 \%$ to the total. An upper limit of $5.5 \times 10^{12} \mathrm{~g} / \mathrm{yr}$ is estimated which is larger than $90 \%$ of all calculated emission rates based on all data categories. This upper limit does not consider uncertainties of the diffusive microlayer approach according to Liss and Merlivat [1986]. The global oceanic emissions are on the low side of previous estimates, and the role of oceanic emissions in global NMHC budyets appears to be of minor importance. Nevertheless, in the remote marine atmosphere the ocean is the dominant source of alkenes [Plass-Diilmer et al., 1993] which have a local impact on the photochemistry [Donahue and Prinn. 1990]

The conclusions remain limited in some aspects. since the data coverage is not uniform. Also, there are still a number of open questions, and some points should be considered in future investigations. Clearly, there is a lack of data from the southern oceans and a lack of complete seasonal cycles at one location. Future measurements of dissolved NMHC should be combined with the measurements of those parameters which are known to have an impact on NMHC concentrations: the wind speed, the insolation, the total DOC concentration, and the photochemical eactive fraction of DOC [Ratle. 1993].

\section{References}

Bonsang, B., and G. Limbert, Nonmethane lydrocarbons in an oceanic atmospherc. J. Atmos. Chem., 2, 257-271, 1985.
Bonsang, B., M. Kanakidou, and G. Lambert, Non methane hydrocarbon chenistry in the atmosphere of an equatorial forest: $A$ case of indirect photochemical production of $\mathrm{OH}$ radicals, Geophys. Res. Lett., 14, 1250-1253, 1987.

Bonsang, B., M. Kanakiclou, G. Lambert, ard P. Monfray, The marine source of $\mathrm{C}_{2}-\mathrm{C}_{6}$ aliphatic hydrocarbons. I. Atmos. Chem., 6, 3-20, 1988.

Bonsang, B., M. Kanakidou, and G. Lamber, On the low relative composition variability of light nonmethane lydrocarbons dissolved in seawater, C. R. Acad. Sci., Ser. 2, 308, 495-500, 1989.

Bonsang. B., D. Martin, G. Lamber, M. Känakidou, J.C. Le Roulley, and G. Sennequier, Vertical distribution of nonmethane hydrocarbons in the remote marine boundary layer, J. Geophys. Res., 96, 7313-7324, 1991.

Brooks, J.E., and W.M. Sackett, Sources, sinks, and concentrations of light hydrocarbons in the Gulf of Mexico, J. Geophys. Res., 78, 5248-5258, 1973.

Brooks, J.E., A.D. Fredericks, W.M. Sackett, and J.W. Swinnerton, Baseline concentrations of light hydrocarbons in Gulf of Mexico, Environ. Sci. Technol., 7.639-642, 1973.

Brown, J., A. Colling, D. Park, J. Phillips, D. Rothery, and J. Wright, Ocean Circulation, edited by G. Bearman, 238 pp., Pergamon, New York, 1989.

Butler, J.H., J.W. Elkins, and T.M. Thompson, Tropospheric and dissolved $\mathrm{N}_{2} \mathrm{O}$ of the west Pacific and east Indian Oceans during the El Nino southern oscillation event of 1987, J. Geophys. Res., 94, 14,865-14,877, 1989.

Donahue, N.M., and R.G. Prinn, Nonmethane hydrocarbon chemistry in the remote marine atmosphere, J. Geophys. Res., 95, 18387$18411,1990$.

Donahue, N.M., and R.G. Prinn, In situ nonmethane hydrocarbon measurements on SAGA 3, J. Geophys. Res., 98, 16,915-16,932, 1993.

Ehhalt, D.H., and J. Rudolph, On the importance of light hydrocarbons in multiphase atmospheric systems, Ber. der Kernforschungsanlage Jïlich, Jül-1942, 43 pp., 1984.

Feldman, G.C., A.Y. Yoder, M.R. Lewis, and P.A. Blanchard, Ocean color from space, report U.S. Global Ocean Flux Study Off., Woods Hole Oceanogr. Instit., Woods Hole, Mass., 1989.

Frank, D.J., W. Sackett, R. Hall, and A Fredericks, Methane, ethane and propane concentrations in Gulf of Mexico, Am. Assoc. Petr. Geol. Bull., 54, 1933-1938, 1970.

Kanakidou, M., Contribution à l'étude des sources des hydrocarbures légers non méthaniques dans l'atmosphére, dissertation, Univ. de Paris VII, Paris, 1988.

Kanakidou, M., B. Bonsang, J.C. Le Roulley, G. Lamber, D. Martin, and G. Sennequier, Marine source of almospheric acetylene, Nanure, 333, 51-52, 1988.

Lamontagne, R.A. Distribution of carton monoxide and $C_{1}-C_{4}$ hydrocarbons in the northeastern portion of the Bering Sea during the summer of 1977, Rep. S356, Nav. Res. Lab., Washingion, D.C., 1979.

L_amontagne, R.A., J.W. Swinnerton, and WV.J. Linnenbom, $C_{1}-C_{4}$ hydrocarbons in the north and south Pacific, Tellus, 26, 71-77, 1974.

Lamontagne, R.A., W.D. Snith, and J.W. Swinnerton, $C_{1}-C_{3}$ hydrocarbons and chlorophyll a concentrations in the equatorial Pacific ocean, in Analylical Methods in Oceanography, edited by T.R.P. Gibb Jr., Adv: Chem. Ser., 147. 163-171, 1975.

I.innenbom, V.J., and J.W. Sivinnerton. Low nolecular weighe hydrocarbons and carbon monoxide in seawater, in Oryanic Matter in Natural Waters, edited by D.W. Hood, pp. 455-467, University of Alaska I'ress, Гairbanks, 1970.

Liss, P'S., and L. Merlivat, Air-sea gas exchange rates: Introduction and synthesis, in The Role of Air-Sea Exchange in Geochenical Cycling, edited by P. Buat-Menard. pp. 113-127, D. Reidel, Norwell, Mass., 1986. 
Macdonald, R.W., Distribution of low molecular weight hydrocarbons in southern Beaufort Sea, Environ. Sci. Tecinol, 10, 1241-46, 1976.

Marine General Staff, Morskoi Allas, vol. 2, Fiziko-geograficskij. edited by the Moskva, Russia, 1953.

Paltridge, G.W., and C.M.R. Platt. Radiative Processes in Meteorology and Climalology, 318 pp., Elsevier, New York, 1976.

Plass, C., R. Koppmann, and J. Rudolph. Measurements of dissolved nonnethane hydrocarbons in seawater, Fresenitus Z Anal. Chem., 339. 746-749, 1991.

Plass, C., R. Koppmann, and J. Rudolph, Light hydrocarbons in the surface water of the nid-Allantic, J. Atmos. Chem., 15, 235-251, 1992.

Plass-Dülmer, C., Die Bedeutung der Ozeane als Quelle für leichte Kohlenwasserstoffe in der Atmosphäre, dissertation, Univ. zu Köln, Cologne, Germany, 1992.

Plass-Dülmer, C., A. Khedim, R. Koppmann, F.J. Johnen, J. Rudolph, and $\mathrm{H}$. Kuosa, Hydrocarbon emissions from the Allantic, Global Biogeochem. Cycles; 7, 211-228, 1993.

Ratte, M. C. Plass-Dülmer, R. Koppmann, J. Rudolph, and J. Denga, Production mechanism of $\mathrm{C}_{2}-\mathrm{C}_{4}$ hydrocarbons in seawater: Field measurements and experiments, Global Biogeochem. Cycles, 7. 369-378, 1993.

Ratte, M., Untersuchungen zum Produktionsmechanismus leichter Nichtmethan-Kohlenwasserstoffe im Meerwasser, dissenation, Rheinisch-Westfälische Technische Hochschule Aachen, Aachen, Germany, 1993.

Rudolph, J., and D.H. Ehhalt, Measurements of $\mathrm{C}_{2}-\mathrm{C}_{5}$ hydrocarbons over the North Atlantic, J.Geophys. Res., 86, 11,959-11,964, 1981.

Sawada, S., and T. Totsuka. Natural and anthropogenic sources and fate of at mospheric ethylene, Atmos. Environ, 20,821-832, 1986.

Suzuki, Y., E. Tanove, and H. Ito, A high-temperature catalıtic oxidation method for the determination of dissolved organic carton in seawater: Analysis and improvement, Deep -Sea Res., Parl A. 39, 185-198, 1992.

Sivinnerton, J.W., and R.A. Lantontagne, The oceanic distribution of low-molecular-weight hydrocarbons, Environ. Sci. Technol., 8 $657-663,1974$

Swinnerton, J.W., and V.J. Linnenbom, Determination of $\mathrm{C}_{1} 10 \mathrm{C}_{4}$ hydrocarbons in seawater by gas chromatography, $J$. Gas Chromalogr., 5, 570-573, 1967a.

Swinnerion, J.W., and V.J. Linnenbom. Gascous hydrocarbons in seawater: Determination, Science, 156, 1119-1120, $1967 \mathrm{~b}$.

Swinnerton, J.W., R. A. Lamontagne, and J.S. Bunt, Fiekl study of carbon monoxide and light hydrocarbon production related 10 natural biological processes, Rep. S099, Nav. Res. Lab.. Washington, D.C., 1977.

U.S. Navy, Marine Climatic Allas of the World, vol. 3, Indian Ocean, Navair 50-IC-529, Washington D.C., 1957.

Wangersky, P.J., Dissolved organic carbon methods: A critical review. Mar. Chem., 4l, 61-74, 1993.

Wilson, D.F., J.W. Swinnerton, and R.A. Lamontagne, Productiou of carbon monoxide and gascous hydrocarbons in seawater: Relation to dissolved organic carbon, Sciencc, 168, 1577-1579, 1970.

R. Koppmann, C. Plass-Dülmer, M. Ratte, and J. Rudolph, Institut fuer Atmosphaerische Chemie, Forschungszentnim Juelich, 52425 Juelich, Germany. (e-mail: r.koppmann@kfa-juelich.de; chr.plassduclmer@kfa-juelich.de; m.ratte@kfa-juelich.de)

(Received September 10, 1993; revised September 7, 1994; accepted September 15, 1994.) 